\title{
Bibliográfia
}

\section{A 2017-ben megjelent, jog- és államtudományi tárgyú könyvek annotált bibliográfiája 2. rész}

Folyóiratunkban - e lapszámmal bezárólag - rendszeresen jelenik meg az elmúlt időszak új, hazai szakkönyveiről készült, annotált bibliográfia. Az annotáció a könyv felhasználhatóságáról írott rövid, tényszerü leírás, amely a bibliográfiai adatok mellett meghatározza a müfajt, illetve röviden körvonalazza a feldolgozott témát és a bemutatott eredményeket is. Mivel folyóiratunk kilencedik évfolyamának két magyar és két angol nyelvü lapszáma jelenik meg, az annotációkat két részletben, az első és a második számban közöljük. A mostani számban a 2017-ben megjelent könyvek második részét dolgozzuk fel. Annak megfelelően, hogy a Magyar Tudományos Művek Tára (MTMT) csak a 120 oldal terjedelmet elérő munkákat kezeli önálló kiadványként, az ettől jelentősen elmaradó (90 oldal alatti) kiadványokat nem annotáljuk. A bemutatás jogterületenként történik, a jogterületek elnevezésének, az egyes jogterületeken belül pedig a szerzők (szerkesztők) nevének ábécérendjében következik.

Első lépésként ezúttal is egy listát állítottunk össze különböző intézményi könyvtári katalógusok, a Magyar Országos Közös Katalógus (MOKKA), illetve az Országos Széchényi Könyvtár interneten is közölt adatai alapján. Emellett kiadók honlapján, hírlevelekben, a szerzők publikációs listáiban és saját könyvespolcainkon is kutattunk. Gyűjtőmunkánkat jelentős mértékben segítette a Debreceni Egyetem Egyetemi és Nemzeti Könyvtára (DEENK), amely köteles könyvtárként a hazai kiadványok gyüjtését, feldolgozását, illetve részben - a mienkhez képest némileg eltérő szempontok szerint - annotálását is elvégzi.

A leírások elkészítése során általában a szerzők, kiadók által készített fülszövegeket, ajánlásokat, illetve a kötetekröl készült recenziókat is igyekszünk fellelni és hasznosítani. Az annotációk azonban minden esetben úgy készültek, hogy magát az adott könyvet is a kezünkbe vettük, s ehhez, ha kellett, könyvtárközi kölcsönzéssel vagy más intézményekben dolgozó kollégáktól megkértük. Az annotációk tehát önálló feldolgozó munka eredményei.

A leírások első, rövidebb része tartalmazza a könyvészeti adatokat (cím, szerző/szerkesztő, a kiadó neve, a kiadás helye és éve) az arra való utalással, hogy van-e a könyvben bibliográfia (irodalomjegyzék), illetve hogy a könyv milyen müfajba sorolható be. A terjedelmet oldalszámban adjuk meg, s közöljük a kötet azonosítására szolgáló ISBN-t, illetve sorozatok esetében az ISSN-t is. A második rész röviden leírja az alkotót, illetve alkotókat. Ezt követően (a változatlan utánnyomá- 
sok kivételével) általában 6-12 sor terjedelemben számba vesszük a mü tárgyköreit, föbb eredményeit. Az eredmények részletes értékelését azonban nem végezzük el (recenziószintü bemutatást nem végzünk). A sokszerzős, illetve a gyüjteményes munkák esetében nem kerül sor valamennyi szerző név szerinti megemlítésére, $s$ a tanulmányok számától, tematikai egymáshoz kapcsolódásától függ, hogy minden témát megnevezünk-e. A felsőoktatási tananyagok, jogszabályközlések bemutatását a lehető legtömörebben végezzük el. A müfaj sajátosságaiból következően az annotáció nem tekinthető az adott müre történő szakirodalmi hivatkozásnak.

Az annotációk szerzői valamilyen formában kivétel nélkül kapcsolódnak a Debreceni Egyetem Állam- és Jogtudományi Karához, legyen szó munkatársainkról, óraadóinkról vagy jelenlegi és volt hallgatóinkról. Az annotációk végén szereplő monogramok, rövidítések feloldása a következő: Ábrók Kamilla (Á. K.) joghallgató, Balogh Judit (B. J.) egyetemi docens, Bak Adrienn (Bak A.) joghallgató, Biczó András (B. A.) PhD-hallgató, Bihari Erika (B. E.) PhD-hallgató, Boros Sándor (B. S.) joghallgató, Deák Izabella (D. I.) kutatási asszisztens, Falusi Bernadett (F. B.) PhD-hallgató, Fazekas Flóra (F. F.) egyetemi adjunktus, Ficsor Krisztina (F. K.) egyetemi adjunktus, Fodor László (F. L.) egyetemi tanár, Gönczi Barbara (G. B.) joghallgató, Handlery Anna (H. A.) joghallgató, Kincses András (K. A.) joghallgató, Kiss Gergely Árpád (K. G. Á.) PhD-hallgató, Mazsu Dániel (M. D.) PhD-hallgató, Megyeri-Pálffi Zoltán (M. P. Z.) egyetemi adjunktus, Pápa Laura (P. L.) joghallgató, Sipos Marcell (S. M.) PhDhallgató, Szabó Béla (Sz. B.) egyetemi tanár, Szepesi Bettina (Sze. B.) PhD-hallgató, Szilágyi Dániel (Sz. D.) PhD-hallgató, Bartha-Tóth Fanni (T. F.) PhD-hallgató, Turányi Noémi (T. N.) PhD-hallgató, Vasas Tamás (V. T.) PhD-hallgató, Újvári Emese (Ú. E.) egyetemi adjunktus.

\section{ALKOTMÁNYJOG}

- Demokrácia, jogállam, közigazgatás. Ünnepi tanulmányok Csefkó Ferenc 70. születésnapjára

Bencsik András-Horváth Csaba (szerk.)

Pécs-Baranyai Értelmiségi Egyesület, Pécs, 2017

Tanulmánykötet. Terjedelem: 399. Bibliográfia a lábjegyzetben. ISBN 9789631280081

- Az ünnepi tanulmánykötet Csefkó Ferenc, a pécsi jogi kar Közigazgatási Jogi Tanszékének címzetes egyetemi docense tiszteletére készült, 70 . születésnapja alkalmából. A kötetben huszonnyolc jogtudományi írás található harmincegy szerző - köztük egyetemi oktatók, miniszterek, alkotmánybírók, főjegyzők - tollából. A címnek megfelelően a szerkesztők négy nagy téma köré csoportosították a tanulmányokat, így olvashatunk írásokat az állam és a jog alapproblémái, a közigazgatási jog és a közigazgatási eljárás, az önkormányzatiság alapkérdései, valamint a társadalomelmélet köréböl is. (Bak A.) 
- Egyes politikai jogok bemutatása: a gyülekezési jog és a petíciós jog alkotmányos szabályozása Magyarországon és a világ más országaiban

Bódı Stefánia

Püski, Budapest, 2017

Monográfia. Terjedelem: 211. Bibliográfia: 189-211. és a fejezetek végén. ISBN 9789633022115

- A szerző a Nemzeti Közszolgálati Egyetem oktatója. A monográfia egybeszerkesztve tartalmazza a szerző korábban megjelent írásait, kiegészítve új kutatási eredményekkel. A szerző igyekszik teljes képet adni a gyülekezési jognak az emberi jogok rendszerén belül elfoglalt helyéröl, valamint a szólásszabadsággal való öszszefüggéseiröl, és a "hagyományos” értelemben vett gyülekezési jog mellett tárgyalja a petíciós jogot is. A magyar gyülekezési és petíciós jogi szabályozás mellett áttekinti az angol, az amerikai, a német, a holland, a francia és a cseh szabályozást is. A monográfia az alapjogi összefüggések vizsgálata és a széles körű nemzetközi elemzések alapján, az alkotmánybírósági gyakorlatra is tekintettel de lege ferenda javaslatokat is megfogalmaz. (D. I.)

- A szabadságszerető embernek. Liber Amicorum István Kukorelli Chronowski Nóra-Pozsár-Szentmiklósy Zoltán-Smuk Péter-Szabó Zsolt (szerk.) Gondolat, Budapest, 2017

Tanulmánykötet. Terjedelem: 901. Bibliográfia a lábjegyzetekben.

ISBN 9789636937706

- Mind terjedelmét, mind a szerzők névsorát tekintve mértékadó tanulmánykötet állt össze Kukorelli István professzor, volt alkotmánybíró 65. születésnapja tiszteletére. A kötet nemcsak az ünnepelt szük szakterületéröl érkező írásokat tartalmaz, hanem azon túli, az ünnepeltet foglalkoztató témaköröket is tárgyal. A szerzők között vannak három jogi kar oktatói, pályatársak, tanítványok és barátok. Az írások közül 75 tanulmány, amelyek az alkotmányfejlödés, alkotmánytörténet, rendszerváltoztatás, parlamentarizmus, alkotmánybíráskodás, illetve az egyetem- és közösségépítés témái köré rendeződnek. Ezek mellett a kötetben az ünnepelt több mint húsz tisztelője személyes hangvételü köszöntőjét is olvashatjuk. (D. I.)

- Választójogi és népszavazási kommentárok

Cserny Ákos-Péteri Attila (szerk.)

(Sorozat: Közigazgatási és jogi kiadványok)

Második, átdolgozott és kiegészített kiadás. Wolters Kluwer, Budapest, 2017 Kommentár. Terjedelem: 552. Bibliográfia nincs. ISBN 9789632956985

- A szerzők egyetemi oktatók. A kiadvány a címben jelzett két tárgykör teljes hazai joganyagának - így az országgyülési képviselök választásáról, a helyi önkormányzati képviselők és polgármesterek választásáról, valamint az Európai Parlament magyar tagjainak választásáról szóló törvények - kommentárját tartalmazza, továbbá ismerteti és kommentálja a nemzetiségi önkormányzati képviselök választási rendjét, és kitér a választási eljárásról szóló törvény bemutatására is. A szerzők az első kiadást kiegészítették a népszavazás kezdeményezéséről, az európai polgári kezdeményezésről, valamint a népszavazási eljárásról szóló 2013. évi CCXXXVIII. törvényhez füzött kommentárral. (D. I.) 
- A nemzetbiztonság kihívásainak hatása a magánszférára

Csink Lóránt (szerk.)

(Sorozat: A Pázmány Péter Katolikus Egyetem Jog- és Államtudományi karának könyvei. Tanulmányok, ISSN 2061-7240; 40.)

Pázmány Press, Budapest, 2017

Tanulmánykötet. Terjedelem: 290. Bibliográfia a lábjegyzetekben.

ISBN 9789633083192

- A szerzők egyetemi oktatók, PhD-hallgatók, gyakorlati szakemberek. A kötet célja, hogy gyakorlatias megközelítésben mutassa be a magánszféra és a nemzetbiztonság kapcsolódási pontjait, vagyis hogy hogyan hangolható össze a szabadság és a biztonság. A szerzők alapgondolata: „biztonság nélkül nincs szabadság, de a szabadság nélküli biztonság értelmezhetetlen". A kötet tárgyalja többek között a titkos információgyüjtés, a minősített adatok védelme, a különleges jogrend és a terrorizmusellenes intézkedések egyes kérdéseit, és a hazai szabályozás mellett Németország, Franciaország és az Egyesült Királyság megoldásait is bemutatja. (G. B.)

- Összehasonlitó módszer az alkotmányjogban

Csink Lóránt-Schanda Balázs (szerk.)

(Sorozat: A Pázmány Péter Katolikus Egyetem Jog- és Államtudományi karának könyvei. Tanulmányok, ISSN 2061-7240; 39.)

Pázmány Press, Budapest, 2017

Tanulmánykötet. Terjedelem: 462. Bibliográfia a lábjegyzetekben. ISBN 9789633083062

- A szerzők a PPKE JÁK, az NKE és az SZTE ÁJK oktatói. A kötet alapját adó kutatás az Igazságügyi Minisztérium A jogászképzés színvonalának emelését célzó programja keretében valósult meg. Ahogy a szerzők a kötet előszavában megfogalmazzák, kevés területen olyan nagy a szakadék elmélet és gyakorlat között, mint az összehasonlító alkotmányjog esetében. Így az említett kutatás során azt tüzték ki célul, hogy az összehasonlító jog elmélete és gyakorlata közti hídépítéshez hozzájáruljanak. Erre tekintettel a kötetben egyrészt az elméleti paradigmákat (pl. globalizáció és nemzeti identitás, jogállamiság, jogrendszerek sajátosságai) kívánták a gyakorlat számára könnyebben hasznosítható módon bemutatni, másrészt az összehasonlító módszert egyes jogintézmények (pl. államfö, törvényhozás és végrehajtás, alkotmánybíráskodás, bíróságok és ügyészségek) vonatkozásában alkalmazni. A kötet elektronikusan teljes terjedelmében, ingyenesen hozzáférhető a PPKE JÁK honlapján. (Á. K.)

- Az alkotmányos párbeszéd: a többszintủ alkotmányosság alkotmánytana és gyakorlata a 21. században

DRINócZI Tímea

MTA TK JTI, Budapest, 2017

Monográfia. Terjedelem: 340. Bibliográfia: 319-340. és a lábjegyzetekben. ISBN 9789634180135

- A szerző egyetemi oktató. Monográfiája, amely MTA doktori értekezésén alapul, az alkotmányos demokráciákban a 21. században megfigyelhető alkotmányos pár- 
beszéd egyes alapvető kérdéseit mutatja be. Így érinti az állami szuverenitás, a hatalommegosztás, az alkotmányozás és alkotmánymódosítás, a tisztességes eljáráshoz való jog, a vallásszabadság és a választási jog területét, amelyeket nemzetközi összehasonlításban, illetve az EJEB és az EUB gyakorlata alapján elemez. A szerző az alkotmányos párbeszéd elméletének segítségével egyes új alkotmányjogi problémák megoldásához és a bevett alkotmányos elvek továbbfejlesztéséhez kíván hozzájárulni, bemutatva az alkotmányos párbeszéd hazai alkalmazásának lehetőségeit. A kötet áttekinti a 2010-2014 közötti magyar alkotmányfejlődés minden fontosabb részkérdését, és azok összegzéseként átfogó alkotmányos jelen- és jövőképet alkot. A mű elektronikusan teljes terjedelmében, ingyenesen hozzáférhető az MTA TK JTI honlapján. (D. I.)

- A személyiség és védelme: az Alaptörvény VI. cikkelyének érvényesülése a magyar jogrendszeren belül

Görög Márta-Menyhárd Attila-Koltay András (szerk.)

ELTE ÁJK, Budapest, 2017

Tanulmánykötet. Terjedelem: 420. Bibliográfia a lábjegyzetekben.

ISBN 9789632849492

- A kötet az ELTE ÁJK, a PPKE JÁK és a SZTE ÁJK közös kutatásának eredményeit mutatja be, amely az Igazságügyi Minisztérium A jogászképzés színvonalának emelését célzó programjának keretében valósult meg. A tanulmánykötet átfogó képet ad a személyiségvédelem aktuális kérdéseiről, a magyar szabályozás és gyakorlat hatékonyságáról, a társadalmi szempontból leginkább érzékeny problémák kezelésének lehetőségeiről. Az írások érintik a magánélethez való jog egyes részaspektusait (például közszereplők, fogvatartottak, internethasználók, rendőrök tekintetében), a joggyakorlat aktuális kérdéseit (például az internetes kommentek vagy a filmalkotás területén), a jogérvényesítési lehetőségeket (az ombudsmani gyakorlatot és a bírói jogalkalmazást), és külön fejezetben foglalkoznak a személyes adatok védelméhez való jog tartalmával és gyakorlatával. A kötet elektronikusan teljes terjedelmében, ingyenesen hozzáférhető a www.eltereader.hu honlapon. (Á. K.)

- Államszervezet és államiság Magyarország Alaptörvényében

Kiss György (szerk.)

Dialóg Campus, Budapest, 2017

Konferenciakötet. Terjedelem: 158. Bibliográfia a lábjegyzetekben és a fejezetek végén. ISBN 9786155764691

- A kötet a magyar Alaptörvény létrejöttének ötödik évfordulója tiszteletére rendezett konferenciasorozat egyik állomásán, a Nemzeti Közszolgálati Egyetemen elhangzott előadások írásos változatát tartalmazza. A konferencia előadásai az Alaptörvény elfogadása körüli vitákat (Szájer József), a történeti alkotmányt (Horváth Attila), az állam és közigazgatás kapcsolatának alaptörvényi megjelenését (Varga Zs. András), a rendészet és a katonaság alaptörvényi kereteit (Orosz Zoltán, Finszter Géza) és az Alaptörvény szimbolikáját (Halász Iván) járták körül. A kötet elektronikusan teljes terjedelmében, ingyenesen hozzáférhető az NKE honlapján. (D. I.) 
- Sajtószabadság és médiajog a 21. század elején 4.

Koltay András-Török Bernát (szerk.)

Wolters Kluwer, Budapest, 2017

Tanulmánykötet. Terjedelem: 526. Bibliográfia a lábjegyzetekben. ISBN 9789632956701

- A kötet az MTA Bölcsészettudományi Kutatóközpontja keretében megalakult Médiatudományi Kutatócsoport kiadványa, amely a „Sajtószabadság és médiajog a 21. század elején" című sorozat negyedik, záró kötete. Az így már csaknem 2500 oldalas széria negyedik kötete a médiaszabályozás, az új média, a személyiségi jogok, illetve a választási eljárások kérdéseit járja körül. A tanulmányok a hazai médiajog, jogalkotás és jogalkalmazás mai helyzetét nemcsak bemutatják, hanem szélesebb kontextusba, euroatlanti összefüggésbe is helyezik. A szerkesztőket valamennyi kötet összeállításakor az a cél vezérelte, hogy a közéleti-politikai vitákkal telített médiaszabályozás és szólásszabadság területén a vizsgált kérdések tudományos-szakmai szempontjaira irányítsák a figyelmet. (D. I.)

- 100 éves a magyar iszlámtörvény

Köbel Szilvia-Tóth J. Zoltán (szerk.)

(Sorozat: Acta Caroliensia Conventorum Scientiarum luridico-Politicarum, ISSN 2063-4757; 20.)

KRE ÁJK, Budapest, 2017

Tanulmánykötet. Terjedelem: 161. Bibliográfia a lábjegyzetben. ISBN 9789639808782

- A magyar iszlámtörvény, az iszlám vallás hazai elismeréséről szóló 1916. évi XVII. tc. megszületésének 2016-ban volt a századik évfordulója. A kötet az ezen alkalomból a KRE-n rendezett konferencián elhangzott 13 előadás írott változatát adja közre. Az előadók többségében jogi egyetemi oktatók, de találunk közöttük vallásjogászt, nemzetközi tanulmányok szakértőt, EMMI főosztályvezetőt és író-történészt is. A jogtörténeti, jogdogmatikai, alapjogi és jogalkotástani megközelítéssel készült egyes írások áttekintik az iszlám elismerésével kapcsolatos magyar jogtörténeti előzményeket, elemzik a magyar iszlám közösség új egyházi státuszát, bemutatják az iszlám jogot és a nemzetközi aktualitásokat. (K. A.)

- Hány éves az Alaptörvény? A régi-új kérdése az Alaptörvényben

KUKORELLI István

Gondolat, Budapest, 2017

Tanulmánykötet. Terjedelem: 268. Bibliográfia az egyes tanulmányok végén és a lábjegyzetekben. ISBN 9789636937430

- A szerző alkotmányjogász, volt alkotmánybíró, az ELTE ÁJK professzora, az MTA doktora. A tematikus tanulmánykötet a 2014-2017 között született írásaiból, konferenciákon elhangzott előadásaiból válogat. A kötet első része inkább elméleti, alkotmányjogi írásokat tartalmaz, a második inkább történeti és személyesebb hangvételü, köszönhetően annak, hogy a szerző résztvevője volt az alkotmányos rendszerváltozás folyamatainak, ezért néhány visszaemlékezése, vele készült interjú is található ebben a fejezetben. A könyv nagy vonalakban a 20. század közepétől 2016-ig követi nyomon a magyar állam és alkotmány történetét, központi 
témája azonban az 1989-90-es alkotmányos rendszerváltozás. A professzor arra keresi a választ, hogy sikeresnek tekinthetö-e alkotmányjogi értelemben a rendszerváltozás, vagy alappal tehető a mai napig bírálat tárgyává. (D. I.)

- Köz/érdek: elméleti és szakjogi megoldások egy klasszikus problémára Lapsánszky András-Smuk Péter-Szigeti Péter (szerk.)

(Sorozat: A Széchenyi István Egyetem Deák Ferenc Állam- és Jogtudományi Karának kiadványai. Juris dictio, ISSN 2416-1500)

Gondolat, Budapest, 2017

Tanulmánykötet. Terjedelem: 652 . Bibliográfia az egyes tanulmányok végén és a lábjegyzetekben. ISBN 9789636937645

- A kötet a Széchenyi István Egyetem jogi karán megvalósult kutatás eredményeit adja közre, amelyben az Alkotmányjogi és Politikatudományi, a Jogelméleti, a Közigazgatási és Pénzügyi Jogi, valamint a Nemzetközi Köz- és Magánjogi Tanszék oktatói és hallgatói vettek részt, és amely az Igazságügyi Minisztérium jogászképzés színvonalának emelését célzó programja keretében valósult meg. A kötet célja a közérdek fogalmának újragondolása, újraértelmezése, a magától értetődő „bevett” alkalmazás megkérdőjelezése a jogtudományban és a joggyakorlatban. A szerzők célja a kutatással az volt, hogy a közérdek ne csupán a magánérdekkel folyamatos harcban álló jelenségként jelenjen meg, hanem a társadalom szolgálatában álló, az egyes magánérdekek összegzéseként is vizsgálható legyen. A közérdek, közjó, közakarat fogalmát körüljáró írások a jogelmélet, az uniós jog, az alkotmányjog és a közigazgatási és pénzügyi jog témaköreihez kapcsolódnak. A kötet elektronikusan teljes terjedelmében, ingyenesen hozzáférhető a Széchenyi István Egyetem honlapján. (Á. K.)

- Emberi jog: tanulmánykötet

Papp László J. (szerk.)

DE ÁJK Praetor Szakkollégium, Debrecen, 2017

Tanulmánykötet. Terjedelem: 147. Bibliográfia a lábjegyzetekben. ISBN 9789634739784

- A debreceni jogi karon müködő Praetor Szakkollégium keretében megjelent kötet a szakkollégium hallgatóinak írásait közli, amelyek témájukban mind valamilyen emberi jogi problémához kapcsolódnak. Így olvashatunk a kötetben az abortusz és az azonos neműek házassága megítéléséről, a nemzetiségek vagy a gyermekek jogainak érvényesíthetőségéröl, illetve a menedékjoggal kapcsolatos kérdésekröl is. (F. F.)

- A szólásszabadság amerikai hagyományának magyarázata. Joggyakorlat alkotmányos értékek és a társadalmi kontextus ölelésében

Post, Robert C.

Koltay András-Török Bernát (szerk.)

Bakonyi László et al. ford.

Wolters Kluwer, Budapest, 2017

Tanulmánykötet. Terjedelem: 792. Bibliográfia a lábjegyzetekben.

ISBN 9789632957029 
- Robert C. Post a szólásszabadság irodalmának nagy hatású alakja. Kötete eltér a szokásos, magyarra fordított külföldi művektöl, hiszen eredeti angol nyelvű változata nincsen. A közzétett tanulmányokat a szerző a kötet szerkesztőivel együttmüködve úgy válogatta össze, hogy azok átfogó képet adjanak a társadalmi kommunikáció jogi megközelítéséről. A kötet első része azokat az írásokat öleli fel, amelyekben Post a szólásszabadság igazoló értékeinek kérdését járja körül. A második rész a demokratikus legitimáció magyarázatában Postnál központi szerephez jutó jogi kategóriát, a társadalmi diskurzust járja körül. A harmadik és negyedik rész a könyv első felében kidolgozott alapokra építve a szólásszabadság kérdéskörének néhány nevezetes problémáját vizsgálja, így a kampányfinanszírozás alkotmányjogi vetületeit, a rasszista szólást, a blaszfémia jogi megítélését és a szólásszabadság és a magánszféra kapcsolatát. (D. I.)

- A szólásszabadság káprázata. A szólásszabadság brit, amerikai és francia klaszszikusainak szöveggyüjteménye

Reményi Édua-Koltay András (szerk.)

Reményi Édua ford.

Wolters Kluwer, Budapest, 2017

Tanulmánykötet. Terjedelem: 562. Bibliográfia a lábjegyzetekben.

ISBN 9789632956824

- A szerkesztők e kötetben azokat a brit, amerikai és francia írásokat gyüjtötték egybe, amelyek a szólás- és sajtószabadság elvi kérdéseit feszegetik, és amelyek az elmúlt évszázadokban-évtizedekben méltán váltak klasszikussá, megkerülhetetlen hivatkozási ponttá. A brit-amerikai fejezetben (amelyhez Horkay Hörcher Ferenc írt bevezető esszét) többek között Milton, Blackstone, Bentham vagy Benjamin Franklin írásait, illetve az amerikai Legfelsőbb Bíróság mérföldkőnek számító döntéseit is olvashatjuk; a francia fejezetben (amelynek bevezetőjét Ludassy Mária írta) találkozhatunk például Condorcet, Mirabeau vagy Victor Hugo esszéivel. A közölt szövegek nagyrészt eddig részben vagy egészben magyarul hozzáférhetetlenek voltak. (F. F.)

- Demokrácia, piacgazdaság, hatalommegosztás

Smuk Péter (szerk.)

Gondolat, Budapest, 2017

Tanulmánykötet. Terjedelem: 306. Bibliográfia az egyes tanulmányok végén és a lábjegyzetekben. ISBN 9789636938437

- A mú a Széchenyi István Egyetem Alkotmányjogi és Politikatudományi Tanszékének nemzetközi kutatási projektjét lezáró tanulmánykötet. A kutatás átfogó hipotézise az volt, hogy Magyarország Alaptörvényének értékrendje és az Alaptörvénybe foglalt közpénzügyi fejezet megújult környezetet jelent az állam és a kormányzat hatáskörei és politikái számára. Tehát a közpénzügyek alaptörvényi szabályozása nem csupán az állam és annak pénzügyei fenntarthatóságát szolgálja, hanem a hatalommegosztás sajátos dimenzióját adja, és így kell egyszerre biztosítania a hatékony kormányzást és a demokratikus jogállami garanciák érvényesülését. A magyar és angol nyelvű, dogmatikai elemzésekre és összehasonlító jogi módszertanra épülő tanulmányok ebböl az alapgondolatból indulnak ki, 
és felölelik az állami szervek hatáskörével, egyes közpolitikákkal, az alkotmányos közpénzügyekkel, a tulajdonhoz való joggal, a piacgazdaság sajátosságaival vagy a közérdek meghatározásával kapcsolatos kérdéseket. A kötet elektronikusan teljes terjedelmében, ingyenesen hozzáférhető a Széchenyi István Egyetem honlapján. (D. I.)

- Különvéleményen a jogállamért! Stumpf István alkotmánybíró különvéleményei 2010-2017

Smuk Péter (szerk.)

Gondolat, Budapest-Győr, 2017

Gyújteményes kötet. Terjedelem: 207. Bibliográfia nincs. ISBN 9789636938130

- A kötetet a győri jogi kar Alkotmányjogi és Politikatudományi Tanszékének munkatársai állították össze Stumpf István alkotmánybíró hatvanadik születésnapjára. A kötetben az ünnepelt által szerzőként jegyzett alkotmánybírói különvéleményei olvashatóak (tehát a mások által jegyzett különvélemények, amelyekhez csatlakozott, illetve párhuzamos indokolásai, amelyek a különvélemények határát súrolják, nem részei a gyűjtésnek). A több mint 40 különvélemény az alkotmányjog legkülönbözőbb területeihez kapcsolódik, így többek között a véleménynyilvánítási szabadsághoz, a választójoghoz, az önkormányzatisághoz és népszavazási kérdésekhez. (D. I.)

- Reinventing Government. Constitutional Changes in Hungary

StumpF István

Gondolat, Budapest, 2017

Tanulmánykötet. Terjedelem: 212. Bibliográfia: 210-212. ISBN 9789636938345

- A szerző jogász, politológus, egyetemi tanár, 2010-2019 között az Alkotmánybíróság tagja. Kötetében az Alaptörvény és a kapcsolódó jogszabályi változások alapján 2011 óta Magyarországon bekövetkezett államszervezeti változások bemutatására és elemzésére vállalkozik. A jogszabályi környezet áttekintése mellett értelmezi az Alkotmánybíróság vonatkozó döntéseit, és a jogi fejleményeket a tudományos és politikai viták kontextusában is értékeli. A kötet három fejezetben a szerző által alkotmánybírói megbízatása alatt írt kilenc tanulmányt, illetve esszét ad közre, amelyekben vissza-visszatérnek a leginkább fontosnak tartott alkotmányjogi kérdések, mint a bírói aktivizmus, a hatalommegosztás, a rendszerváltás vagy a 2011-es alkotmányozási eljárás értékelése. (F. F.)

- Szakmai elemzések a jogszabályok hatályosulásának vizsgálatára

Szabolcsi László-Juhász Zoltán-Varga Éva Csilla (szerk.)

Magyar Közlöny Lap- és Könyvkiadó, Budapest, 2017

Tanulmánykötet. Terjedelem: 207. Bibliográfia a lábjegyzetekben. ISBN 9786155710100

- A kötet az Igazságügyi Minisztérium által végzett szakmai elemző tevékenységet mutatja be, amely célja elsősorban, hogy tárgyszerü háttéranyagokkal segítse a kodifikációs munkálatokat, hozzájáruljon a jogalkotás minőségének javulásához. Az összeállításban megtaláljuk többek között az új polgári perrendtartáshoz és az 
új közigazgatási eljárási törvényhez kapcsolódó minisztériumi elemzéseket, valamint szakmai háttértanulmányokat olvashatunk például a törvényességi felügyelet jogintézményének hazai szabályozásáról. Az elemzések alapvetően a vonatkozó bírósági ítéleteken (ideértve az AB és az EJEB gyakorlatát), a joggyakorlaton és az igazságügyi statisztikai adatokon alapulnak, de reflektálnak a vonatkozó szakirodalomra is. (P. L)

- Bérc avagy a joguralom útjai. Alkotmány- és politikaelemzések száz tételben, 2005-2015

SZENTPÉTERI NAGY Richard

Noran Libro, Budapest, 2017

Tanulmánykötet. Terjedelem: 479. Bibliográfia a lábjegyzetekben. ISBN 9786155667633

- A szerző a Nemzeti Közszolgálati Egyetem oktatója. Kötete a 2005 és 2015 között íródott alkotmányjogi és politológiai elemzéseit tartalmazza száz fejezetben. A mü által felölelt évtizedben előbb az Alkotmány, majd az Alaptörvény volt hatályban: a szerző mindkét alapokmány tartalmát kritikusan elemzi. Az Alkotmány kapcsán kitér például a határon túli magyarok helyzetére vagy a konstruktív bizalmatlansági indítványra; az Alaptörvény kapcsán többek között annak legitimációjával, preambulumával és annak szakrális jellegével is foglalkozik. A magyarországi kormányzásról, annak lehetőségeiről és útjairól a rendszerváltástól 2015-ig terjedő időszakra nézve olvashatunk elemzéseket, ideértve a jelenleg is hatalmon lévő kormány tevékenységét, illetve a kormányformával, valamint a hatalmi ágak tényleges elválásával kapcsolatos aktuális kérdéseket. (P. L.)

\section{- A honvédelmi alkotmányosság 30 éve Magyarországon, 1988-2017}

TILL Szabolcs

Zrínyi, Budapest, 2017

Monográfia. Terjedelem: 319. Bibliográfia: 295-317. és a lábjegyzetekben. ISBN 9789633275436

- A szerző 30 éves honvédelmi tapasztalattal rendelkező ezredes. Munkája, amely a 2015-ben a politikatudományok területén megvédett doktori értekezésén alapszik, a rendszerváltástól napjainkig tekinti át a magyar honvédelmi jogalkotást, különösen annak alkotmányos szintü - meglehetősen nagy volumenü - változásait a megjelölt időszakban. Ezzel egy átlátható és hatékony jövőbeli szabályozási rendszer kialakításához is hozzá kíván járulni. A kötet az államszervezeti keretek, az irányítási kérdések vagy a különleges jogrendre vonatkozó szabályozás áttekintése mellett a kapcsolódó alapjogi problémákra (mint a lőfegyverhasználat vagy a véleménynyilvánítási szabadság egyes részkérdései) is kitér. (K. A.)

- 5 éves az Alaptörvény. Válogatás az ünnepi konferenciasorozat beszédeiböl Vízkelety Mariann (fószerk.) Magyar Közlöny Lap- és Könyvkiadó, Budapest, 2017 Konferenciakötet. Terjedelem: 301. Bibliográfia a lábjegyzetekben. ISBN 9786155710117 
- A kötet az Alaptörvény elfogadásának ötödik évfordulója alkalmából 2016-ban rendezett konferenciasorozatban (így Debrecenben, Budapesten, Esztergomban, Székesfehérváron és Ópusztaszeren) elhangzott előadásokból válogat. A szerzők többségükben jogászok (köztük olyanok is, akik az oktatás mellett közéleti szerepet is betöltenek), de találunk köztük egyházi és egyetemi vezetőket is. A tanulmányok alapjául szolgáló előadásokból az olvasó képet kaphat az Alaptörvény történetéröl, előzményeiről, a történeti alkotmányhoz való viszonyáról, valamint a jelent foglalkoztató aktuális kérdésekről: például az igazságszolgáltatás átalakulásáról, a honvédelemről, a nemzetállami keretekben gyakorolt állami szuverenitásról vagy a globalizáció okozta kihívásokról is. (D. I.)

\section{EURÓPA-JOG ÉS NEMZETKÖZI JOG}

- Bevezetés az Európai Unió belső piacának jogába és joggyakorlatába ANGYAL Zoltán

ME ÁJK Európai és Nemzetközi Jogi Intézet, Miskolc, 2017

Egyetemi jegyzet. Terjedelem: 220. Bibliográfia: 213-220. és a lábjegyzetekben. ISBN 9786158021234

- A szerző a miskolci jogi kar tanszékvezető egyetemi docense. A tankönyv célja, hogy átfogó és átlátható rendszerbe foglalja össze az Európai Unió belső piacára vonatkozó szabályokat és joggyakorlatot. A területre vonatkozó elsődleges és másodlagos jogi normákat az Európai Unió Bírósága vonatkozó joggyakorlatával egészíti ki. Nem törekszik a téma teljes körü, valamennyi részterületre vonatkozó feldolgozására, hanem az alap- és mesterszakos hallgatók számára tankönyvként, a gyakorló jogászoknak kézikönyvként kíván szolgálni. (M. D.)

- Szuverenitás és államiság az Európai Unióban. Kortárs kérdések és kihívások Chronowski Nóra (szerk.)

ELTE Eötvös Kiadó, Budapest, 2017

Tanulmánykötet. Terjedelem: 278. Bibliográfia a lábjegyzetekben.

ISBN 9789632849171

- A szerzők egyetemi oktatók, kutatók, PhD-hallgatók. A kötet az Igazságügyi Minisztérium támogatásával, 2017 januárja és szeptembere között megvalósult, Terület, lakosság, főhatalom a 21. században című kutatási projekt keretében született. A projekt egyik legfontosabb célkitüzése az volt, hogy a szuverenitás és az államiság kérdéskörét az európai alkotmányos térség sajátos kontextusában vizsgálja, így a kötetben helyet kapott tanulmányok döntően az állami szuverenitás olyan aktuális kihívásaival foglalkoznak, amelyek az Európai Unió tagállamait e minőségükben érintik. A vizsgált témakörök között megjelennek az uniós és tagállami jogok közötti kollíziós viták, illetve a tagállami alkotmánybíróságok és parlamentek lehetőségei azok megoldásában, továbbá több tanulmány is foglalkozik a migráció, valamint a nemzetközi alapjogvédelem területein felmerülő, állami szuverenitást érintő kérdésekkel. (Sz. D.) 
- Az európai uniós koordináció Magyarországon és a magyar nemzeti érdek az Európai Unióban

CsatLós Erzsébet

(Sorozat: Fundamenta Fontium Juris Administrationis, ISSN 2061-1609)

lurisperitus, Szeged, 2017

Monográfia. Terjedelem: 144. Bibliográfia: 135-144. ISBN 9786155411496

- A szerző a szegedi jogi kar oktatója, aki monográfiájában a magyar közigazgatás és az Európai Unió intézményrendszere közötti kapcsolatot elsősorban a magyar nemzeti érdekek kialakításának és azok uniós döntéshozatalban való képviseletének szemszögéből vizsgálja. A kötet ennek keretében mind a tagállami érdekérvényesítés uniós intézményrendszeren belüli fórumait, mind pedig az uniós ügyek kormányzati koordinációjának hazai rendszerét mutatja a végrehajtó hatalmi ág szerepe mellett kitérve a magyar Országgyűlést megillető jogkörökre is az uniós jogalkotási és döntéshozatali folyamatban. (Sz. D.)

- Az Európai Unió joga

Gombos Katalin

Patrocinium, Budapest, 2017

Tankönyv. Terjedelem: 359. Bibliográfia nincs. ISBN 9789634131830

- A szerző az NKE Európai Köz- és Magánjogi Tanszékének vezetője, kúriai bíró. A könyv elsősorban a jogi szakvizsgára készülő jogászoknak készült tansegédlet, amely első részében az Európai Unió jogrendszerét tekinti át az intézményektől kezdődően a jogforrási rendszeren és az Európai Bíróság eljárásain át a belső piac alapelveivel és szabadságaival bezárólag. Az ismeretek könnyebb elsajátíthatóságát segíti, hogy a kötet valamennyi fejezet elején áttekintést ad az elsődleges és másodlagos uniós jog releváns rendelkezéseiröl, és az egyes fejezetek végén ellenőrző kérdéseket is tartalmaz. A kötet második része a legfontosabb másodlagos uniós jogforrások szövegét adja közre. (M. D.)

\section{- Az Európai Unió jogrendszere és közjogának alapjai}

Gombos Katalin

Wolters Kluwer, Budapest, 2017

Tankönyv/kézikönyv. Terjedelem: 467. Bibliográfia: 425-433. és lábjegyzetekben. ISBN 9789632956503

- A szerző az NKE Európai Köz- és Magánjogi Tanszékének vezetője, kúriai bíró. A gyakorló jogászok számára kézikönyvként is jól használható kötetben átfogóan mutatja be az Európai Uniós jog- és intézményrendszert. Elsőként az Európai Unió történetét tekinti át (kiemelve Magyarország és az európai integráció kapcsolatának alakulását), majd ismerteti az uniós jogrend alapvető elveit (közvetlen hatály, elsőbbség, uniós célkitűzések), az intézményrendszert, a hatásköri szabályokat, a jogforrási és döntéshozatali rendszert és a bírósági eljárásokat. Az utolsó fejezetek az uniós jog kikényszerítésének lehetőségeit, az uniós alapjogvédelmi rendszert és az uniós polgárság intézményét mutatják be. (H. A.) 
- Nemzetközi jog

Kardos Gábor-Lattmann Tamás (szerk.)

(Sorozat: ELTE jogi kari tankönyvek, ISSN 2060-6494; 3.)

ELTE Eötvös, Budapest, 2017

Tankönyv. Terjedelem: 497. Bibliográfia: 477-479. ISBN 9789633120224

- A 2010-es kiadás változatlan utánnyomása. Annotációja a Pro Futuro 2012/1. számában található. (F. B.)

- Európai közjog és politika

Kende Tamás-Szücs Tamás-Jeney Petra (szerk.)

Harmadik, átdolgozott kiadás. Wolters Kluwer, Budapest, 2017

Kézikönyv. Terjedelem: 807. Bibliográfia az egyes fejezetek végén.

ISBN 9789632956848.

- A szerzők az ELTE Állam- és Jogtudományi Karának oktatói és gyakorló európai jogászok. Az uniós jogi tanulmányok körében alapmünek számító kötet új kiadása komoly tartalmi változtatásokon esett át, tekintettel a legutóbbi kiadás 2007-es megjelenése óta végbement fejleményekre. A kötet átfogó képet nyújt többek között az európai integráció történetéröl, az Európai Unió jogi és intézményi felépítéséről, jogalkotási és döntéshozatali eljárásairól, pénzügyi és külkapcsolati rendszeréröl, valamint az Európai Unió Bíróságának eljárásairól. Az Európai Unió és a tagállamok kapcsolatának különböző aspektusai a kötet több pontján is elemzésre kerülnek: így külön fejezet tárgyalja a hatáskörmegosztás kérdését, illetve az uniós jog és a tagállami jog viszonyát; önálló fejezet foglalkozik továbbá az Unió és Magyarország kapcsolatának sajátosságaival. A harmadik kiadás újdonságai közé tartozik, hogy a Lisszaboni Szerződés mellett a legfrissebb eseményeket, a gazdasági és migrációs válságot, az Egyesült Királyság kilépéséről folyó tárgyalásokat és az Európa jövőjét illető legújabb terveket is értékeli. (Sz. D.)

- Az Egyesült Királyság kilépése az EU-ból és az európai integráció

Losoncz Miklós

(Sorozat: Prosperitas monográfiák, ISSN 2063-7438)

BGE, Budapest, 2017

Monográfia. Terjedelem: 256. Bibliográfia: 255-272. ISBN 978-615-5607-35-6

- A szerző közgazdász, egyetemi tanár, az MTA doktora. Kötetében komplex módon mutatja be és elemzi az Egyesült Királyság Európai Unióból való kilépésének körülményeit és lehetséges következményeit mind az Egyesült Királyságra, mind az Unióra nézve, és kitér a folyamat globális hatásaira is. Az Európai Unióból történő brit kilépés (közismert nevén Brexit) előzményeit, jogi és intézményi vonatkozásait, lehetséges megoldási alternatíváit, valamint gazdasági és politikai következményeit is vizsgálja. A Brexit közgazdasági, politikai és diplomáciai vonatkozásai egyszerre jelennek meg a szerző értékelésében, így nemcsak a közgazdászok számára nyújt átfogó képet a brit kilépés körülményeiröl és várható következményeiröl, hanem más szakmák képviselőinek, így a jogászoknak is. (M. D.) 
- Európai integrációs alapismeretek

MIKLÓSNÉ ZAKAR Andrea

(Sorozat: Bethlen-sorozat, ISSN 2062-2546)

Patrocinium, Budapest, 2017

Egyetemi jegyzet. Terjedelem: 142. Bibliográfia: 141-142. és a lábjegyzetekben. ISBN 9789634131595

- A szerző a KRE oktatója. Jegyzetében az európai uniós ismeretek vázlatos áttekintését adja elsősorban az alapszakos képzésben részt vevő hallgatók számára. A kötet átfogó képet ad az Európai Unió történetét, struktúráját és működését illetően, az ismereteket tematikus fejezetekre osztja, melyekben a legalapvetőbb tudnivalókat emeli ki, és a fejezetek végén összefoglaló kérdéseket fogalmaz meg. A kötet külön fejezetben foglalkozik az elsődleges és másodlagos jogforrásokkal, az Európai Unió intézményrendszerével, valamint kitér Magyarország és az Európai Unió kapcsolatára. (H. A.)

- Basics of European Union Law

Pelle Anita-Váradi Szilvia (szerk.)

(Sorozat: Fundamenta Fontium luris Internationalis, ISSN 2560-063X)

lurisperitus, Szeged, 2017

Egyetemi jegyzet. Terjedelem: 140. Bibliográfia: 135-140. ISBN 9786155411601

- A szerzők a Szegedi Tudományegyetem oktatói. A könyv célja, hogy az Európai Unióról konkrét ismeretekkel még csak érintőlegesen vagy egyáltalán nem rendelkező olvasóknak tömör, de átfogó képet adjon az európai integráció müködéséről, annak előzményeitől kezdve az intézményeken és a jogrendszeren keresztül egészen az uniós versenyszabályozásig. A kötet angol nyelvű, így megfelelő alapozó olvasmány lehet a harmadik országokból érkező hallgatóknak is: a szerzők maguk is kifejezetten ajánlják a könyvet erre a célra. Minden fejezet a tanulási célok felsorolásával kezdődik és egy rövid összefoglalóval ér véget, ezáltal is segítve az olvasókat a téma megértésében és megtanulásában. (M. D.)

- Az Európai Unió a világban. Uniós külkapcsolatok a 21. században

Simon Zoltán (szerk.)

(Sorozat: Föld-rész könyvek, ISSN 2060-5404)

L'Harmattan, Budapest, 2017

Tankönyv/kézikönyv. Terjedelem: 366. Bibliográfia az egyes fejezetek végén. ISBN 9789634142966

- A szerzők egyetemi oktatók, gyakorlati szakemberek, akik között jogászt, bölcsészt és közgazdászt is találunk. A tankönyvként is használható kötet 14 fejezetben mutatja be az európai integrációs szervezet külkapcsolati rendszerét és politikáit. A fogalmi és történeti bevezetést követő fejezetek egyrészt elméleti megközelítést nyújtanak (például az uniós külkapcsolatok alapelveinek, intézményeinek bemutatásával), másrészt az egyes külkapcsolati politikákat (közös kül- és biztonságpolitika, nemzetközi humanitárius segítségnyújtás stb.) és a közelebbi s távolabbi jövőben csatlakozni szándékozó államokkal fennálló külkapcsolatokat mutatja be. (F. F.) 


\section{- Az Európai Unió jogi fundamentumai}

Szabó Marcel-Láncos Petra Lea-Gyeney Laura (szerk.)

Hetedik, javított kiadás. Szent István Társulat, Budapest, 2017

Tankönyv. Terjedelem: 334. Bibliográfia a lábjegyzetekben. ISBN 9789632776972

- A szerzők a PPKE JÁK oktatói. A joghallgatók számára készített mű két nagy témakört tárgyal. Az első rész témája az Európai Unió története, jog- és intézményrendszere, a közös kül- és biztonságpolitika alapjai, valamint az Európai Unió jogalanyisága, amellyel kapcsolatban a szerzők három alapvető nemzetközi közjogi fogalmat vizsgálnak: a kormányközi nemzetközi szervezet, az államszövetség és a szövetségi állam sajátosságait. A második rész rövid bevezetővel kezdődik a belső piac működésével kapcsolatban, amit az Európai Unió gazdasági alkotmánya, az áruk, munkavállalók, uniós polgárok és személyek szabad mozgása, valamint a szolgáltatásnyújtás, tőke és fizetési müveletek szabadsága követ. Végezetül a könyv kitér a belső piac és az alapjogok kapcsolatára, kiemelve az Európai Unió Bíróságának szerepét ezen a területen. A kötet 2012 óta évente újabb kiadásban jelent meg, az első kiadás annotációja a Pro Futuro 2014/2. számában található. (H. A.)

\section{- Basics of International Law. Course Book}

SzIEBIg Orsolya Johanna

(Sorozat: Fundamenta Fontium luris Internationalis, ISSN 2560-063X)

lurisperitus, Szeged, 2017

Egyetemi jegyzet. Terjedelem: 104. Bibliográfia: 101-104. és a lábjegyzetekben. ISBN 9786155411588

- A szerző a SZTE ÁJTK oktatója. A jegyzet angol nyelvü egyetemi képzésekhez készült. A nemzetközi közjogi tanulmányok kiindulópontját képező részterületek összefoglalását adja: a nemzetközi jog történetét követően a jogforrásokat, a jogalanyokat és az alapelveket ismerteti. A jogforrások közül a nemzetközi szerződések, az alapelvek köréből pedig a viták békés rendezése külön fejezetben részletesebben is megjelennek. A jegyzet végezetül az államfelelősség témakörével foglalkozik. A szerkezeti egységek végén ellenőrző kérdésekként funkcionáló kulcsszó-listák, valamint ajánlott irodalom találhatók. (F. B.)

\section{- Az EU-jog alkalmazása. Kézikönyv gyakorló jogászoknak} VARGa Zsófia Wolters Kluwer, Budapest, 2017 Kézikönyv. Terjedelem: 314. Bibliográfia: 303-314. ISBN 9789632956565

- A szerző gyakorló európai jogász, az Európai Unió Bíróságának korábbi munkatársa. Kötetében arra törekszik, hogy az Európai Unió jogrendszerével foglalkozó, magyar nyelven korábban megjelent munkák többségétől eltérően kifejezetten gyakorlati nézőpontból mutassa be az uniós jogot, ezáltal segítve a magyar jogalkalmazókat - így különösen a hazai bírákat és ügyvédeket - az uniós jog megértésében és helyes alkalmazásában. A kötet átfogó képet ad mindazokról a forrásokról, amelyekből az Európai Unió Bíróságának ítélkezési gyakorlata megismerhető, bemutatja a magyar bíróságokat az uniós jog alkalmazásával össze- 
függésben terhelö kötelezettségeket, valamint mindazokat az eseteket, amikor hivatalból kötelesek alkalmazni az uniós jogot. A tagállamok kártérítési felelőssége, az előzetes döntéshozatali eljárás szabályai, valamint az Alapjogi Charta alkalmazási köre egyaránt részletes, a luxemburgi bíróság ítélkezési gyakorlatát következetesen felvázoló fejezetekben kerülnek bemutatásra. (Sz. D.)

- A kötelezettségszegési eljárások jogiasodása az Európai Unióban VÁRnAY Ernő

Debreceni Egyetemi Kiadó, Debrecen, 2017 Monográfia. Terjedelem: 279. Bibliográfia: 269-279. ISBN 9789633180662

- A szerző egyetemi tanár, az MTA TK JTI tudományos tanácsadója. A kötet célja, hogy bemutassa, miként váltak az Európai Unió Müködéséröl szóló Szerződés 258. és 260. cikkében szereplő, ún. kötelezettségszegési eljárások egy döntően politikai jellegű eljárásból intézményesült-jogiasodott processzussá. E folyamat áttekintése során a kötet komplex módon, számos részletre kiterjedően mutatja be az Európai Unió Bíróságának kötelezettségszegési ügyeket érintő ítélkezési gyakorlatát. A Bíróság esetjogának feldolgozásán túl a kötet külön fejezetben foglalkozik például az eljárásokat szabályozó alapszerződési rendelkezések „alkotmányosodásával", valamint az európai ombudsman fellépésével a kötelezettségszegési eljárások panaszosai pozíciójának javításáért. (Sz. D.)

- Az európai családjog gyakorlata. Az Európai Unió Bíróságának családjogi tárgyú uniós rendeletekkel kapcsolatos joggyakorlata

WOPERA Zsuzsa

Complex, Budapest, 2017

Kézikönyv. Terjedelem: 182. Bibliográfia: 179-180. ISBN 9789632956541.

- A szerző a Miskolci Egyetem Állam- és Jogtudományi Karának egyetemi tanára. A kézikönyv célja, hogy az Európai Unió Bírósága ítélkezési gyakorlatának elemzésén keresztül bemutassa a határon átnyúló családjogi jogviták fejlődési tendenciáit, az e jogvitákban felmerülő leggyakoribb jogalkalmazási problémákat, valamint a Bíróság ezekre adott válaszait. A kötet struktúrája a hatályos európai családjogi szabályozást megalapozó Brüsszel lla. tanácsi rendelet felépítését követi: az egyes fejezetek a rendelet legfontosabb szakaszai mentén mutatják be a Bíróság - döntően a hatállyal, joghatósággal és a közrenddel foglalkozó - esetjogát. (Sz. D.)

\section{JOGBÖLCSELET}

- A jogtudat narratív értelmezése

Fleck Zoltán-Kiss Valéria-Tóth Fruzsina-Neumann László-Kenéz Anikó- Bajnok Dávid

ELTE Eötvös, Budapest, 2017

Monográfia. Terjedelem: 366. Bibliográfia: 366. és a lábjegyzetekben.

ISBN 9789632849508 
- A kötet szerzői Fleck Zoltán, az ELTE ÁJK Jog- és Társadalomelméleti Tanszékének vezetője által müködtetett szellemi mühelyhez tartozó kutatók, egyetemi oktatók. A társadalom tagjai jogról alkotott elképzeléseinek empirikus vizsgálata alapvető fontosságú a jog természetének és müködésének megértése szempontjából. A jogtudat-kutatások célja, hogy megvilágítsák, a jog miképpen hat a társadalmi gyakorlatokra és az egyének cselekvésére. A kötet speciális nézőpontból közelíti meg ezt a kérdést, méghozzá az ún. narratív értelmezés keretében mozog. A kötet szerzői amellett érvelnek, hogy azok a narratívák, amelyek keretében a társadalom tagjai értelmezik, illetve maguk számára értelmessé teszik a körülöttük lévő világot és cselekvéseiket, a jogtudatot is tükrözik. Ezért az egyének narratíváinak vizsgálatával a jog természetéről is szélesebb körü ismereteket szerezhetünk. A kötet első részében az elemzés elméleti-módszertani alapjait, második részében az empirikus vizsgálódásokat, harmadik részében az életinterjú-elemzéseket mutatja be. (V. T.)

- A természetjog napja

Frivaldszky János-Tussay Ákos (szerk.)

(Sorozat: A Pázmány Péter Katolikus Egyetem Jog- és Államtudományi Karának Könyvei, Tanulmányok, ISSN 2061-7240; 41.)

PPKE JÁK, Budapest, 2017

Konferenciakiadvány. Terjedelem: 373. Bibliográfia az egyes fejezetek végén. ISBN 9789633083239

- A kötet a 2016. május 26-án és 2017. május 27-én megrendezett, a Természetjog Napja I-II. címú konferenciákon elhangzott elöadások szerkesztett szövegeit tartalmazza. A konferencia alkalmából mindkét évben átadták a Természetjog kiváló kutatója díjat. A kiadvány a díjazottak előadásainak szövegeit, valamint egy megemlékezést tartalmaz. A tanulmányok szerzői és előadói jogászok, egyházjogászok, filozófiakutatók. Az előadások tematikája kiterjed a világi jogtudományra, az egyházjogra, a filozófiai etikára, illetve a természetjog történeti és vallási aspektusaira is. (V. T.)

\section{- Jogelméleti előadások}

KARÁcsony András

(Sorozat: ELTE Jogi Kari Jegyzetek, ISSN 2060-5986; 24.)

ELTE Eötvös Kiadó, Budapest, 2017

Tankönyv/tanulmánykötet. Terjedelem: 207. Bibliográfia az egyes fejezetek végén. ISBN 9789633122747

- A szerző jogfilozófus, az ELTE egyetemi tanára. Könyve elsősorban joghallgatóknak készült, mely 11 fejezeten keresztül a jogelmélet legfontosabb kérdéseivel, irányzataival foglalkozik. A 13. századtól a 20. századig áttekinti a föbb jogelméleti állomásokat, társadalomelméleti kérdéseket. A jogtudomány, jogfilozófia fogalmi meghatározásától a jogi hermeneutika és döntéselmélet problémáján át a demokratikus jogállam koncepciójáig számos jogbölcseleti munkát és jogelméleti iskolát bemutat. Külön fejezet foglalkozik például Carl Schmitt, Radbruch, Luhmann vagy Rawls munkásságának egy-egy aspektusával is. (G. B.) 
- Jogászi etika és felelösség

NAGY Zsolt-Tóth Judit

(Sorozat: Fundamenta Fontium luris, ISSN 2061-1609; 11.)

lurisperitus, Szeged, 2017

Tankönyv. Terjedelem: 254. Bibliográfia az egyes fejezetek végén.

ISBN 9786155411618

- A szerzők a szegedi jogi kar Alkotmányjogi Tanszékének oktatói. A kiadvány a jogászi etika oktatásához készült, de kiindulópontként általános etikai ismereteket is tartalmaz. A témát különböző vitakérdések és dilemmák (mint az ügyvédi titoktartás, a bírák megvesztegethetősége vagy a szakdolgozatokkal kapcsolatos plágium) bemutatásával járja körül, melyet két nagy fejezetben foglal össze. A könyv melléklete tartalmazza a vonatkozó jogszabályanyagot, illetve Spiró György Széljegy című színdarabját, amely az ügyvédi hivatás gyakorlásának etikai kérdéseihez kapcsolódik. (G. B.)

- Unitas multiplex. Ünnepi tanulmányok Szigeti Péter 65. születésnapjára

Takács Péter (szerk.)

(Sorozat: Jurisdictio, ISSN 2416-1500)

Gondolat-SZE DFK, Budapest-Győr, 2017

Tanulmánykötet. Terjedelem: 464. Bibliográfia a lábjegyzetekben.

ISBN 9789636938079

- A kötet szerzői különböző hazai felsőoktatási intézmények, tudományos szervezetek oktatói, doktoranduszai, akik Szigeti Péter 65. születésnapja alkalmából a kiadványban egy-egy tanulmánnyal fejezik ki tiszteletüket az ünnepelt professzor iránt. Szigeti Péter a győri Széchenyi István Egyetem Állam- és Jogtudományi Kar Jogelméleti Tanszékének oktatója, egykori vezetője, illetve a kar Állam- és Jogtudományi Doktori Iskolájának vezetője. A tanulmányok a jog- és államtudományok, a rendészeti tudományok, a közgazdaságtan, és a szociológia világából kiragadott témákba nyújtanak betekintést. A kiadvány bemutatja továbbá Szigeti Péter szakmai életútját, tartalmazza tudományos munkáinak jegyzékét, és az ünnepelt esemény alkalmából 2016. november 14-én, Győrben tartott konferencia programját. (V. T.)

- A jurisztokratikus állam

Pokol Béla

Dialóg Campus, Budapest, 2017

Monográfia. Terjedelem: 159. Bibliográfia: 155-159. ISBN 9786155680519

- A mü szerzője jogfilozófus, alkotmánybíró. A jogfilozófia gyakran elemzett területe a jog és politika közötti viszony természete. A jog és politika közötti összefüggések helyes feltárása függ attól, hogy miképpen gondolkodunk a politika fogalmáról és a jog természetéröl. $E$ kérdés kutatása közben a könyv szerzője sajátos filozófiai álláspontot alakított ki: megfigyelése szerint az ezredforduló után egyre inkább jellemző az ún. bírói (jurisztokratikus) államok kialakulása, amelynek legfontosabb következménye, hogy a demokratikus intézmények háttérbe szorulnak, a választók akaratának érvényesítése pedig veszélybe kerül. A jurisztokratikus 
állam jellemző tulajdonsága ugyanis, hogy a szembenálló társadalmi érdekeket képviselö csoportok harca átkerül a parlamenti választási küzdelmekből, valamint a törvényhozási eljárásból a bírói tárgyalótermekbe, ezáltal a társadalmi problémák megoldása nem törvényhozási, hanem bírói úton történik. E folyamat veszélyeit a szerző hét fejezetben tárgyalja, érintve a jurisztokratikus kormányformák, a perlési politizálás sajátosságait, és a mindezek hátterében meghúzódó morálfilozófiát. (F. K.)

- A szegedi jogbölcseleti iskola alapítója. Horváth Barna emlékkönyv

Révész Béla (szerk.)

(Sorozat: A Pólay Elemér Alapítvány Könyvtára, ISSN 1786-352X; 67.)

lurisperitus, Szeged, 2017

Emlékkönyv. Terjedelem: 408. Bibliográfia a lábjegyzetekben.

ISBN 9786155411540

- A kötet szerkesztője Révész Béla, a Szegedi Tudományegyetem Állam- és Jogtudományi Kar Politológia Tanszékének oktatója. A mú a szegedi jogtudományi oktatás neves magyar jogfilozófusának, Horváth Barnának állít emléket. Horváth Barna XX. század közepétöl kibontakozó jogtudományának sajátossága az ún. szinoptikus látásmód alapjainak kidolgozása. Jogszemléletére erősen hatott az angolszász jogi kultúra és gondolkodás, amelynek eredményeként egyik legjelentősebb műve, az Angol jogelmélet 1943-ban született meg. A Révész Béla által szerkesztett kötetben jogászok, politológusok, szociológusok tanulmányai kaptak helyet, nagyrészt az emlékkönyv által méltatott személy tudományos munkásságához kapcsolódó témákat dolgoztak fel. A kiadás gazdag tartalmi eleme Horváth Barna szakmai-személyes életútjának bemutatása bibliográfiával, írásos hagyatékokkal, fotográfiai dokumentumokkal. (V. T.)

- Jog és nyelv határán. A jogi nye/vhasználat nemzetközi és hazai kutatása VINNAI Edina

(Sorozat: Recta Ratio, ISSN 2064-7107)

Gondolat Kiadó, Budapest, 2017 Monográfia. Terjedelem: 274. Bibliográfia: 251-268. és a lábjegyzetekben. ISBN 9789636938253

- A jog egyik alapvető tulajdonsága, hogy a természetes nyelv segítségével közvetíti előírásait. A jog természetének, müködésének megértéséhez ezért nagyban hozzájárulnak az olyan kutatások, amelyek a jog nyelvi dimenzióit világítják meg. E könyv szerzőjének központi állítása, hogy a tisztességes eljárás fontos követelménye, hogy az eljárás résztvevői egyrészt ismertethessék és megértethessék egymással álláspontjukat; másrészt az is, hogy a felek számára világosak legyenek az eljárás egyes lépései és az eljárásban velük közölt határozatok, ítéletek. A könyv a jogi nyelvhasználat nyelvfilozófiai, illetve empirikus kutatásán keresztül mutatja be, hogy a jogi eljárás résztvevői közötti kommunikáció hiányosságai kihatással lehetnek az eljárás eredményére és annak végrehajtására. Ezért a jog nyelvi dimenziójának feltárása a jog legitimitásának és az állampolgárok jogi kötelezettségeinek megalapozásában is fontos szerepet játszik. A monográfia három 
fejezeten keresztül mutatja be a „jog és nyelv” kutatások módszereit, jelentőségét és a szerző empirikus kutatásainak eredményeit, következtetéseit. (F. K.)

- Ins Herz geschrieben. A szívébe írva. A természetjog mint az emberi társadalom alapja

WALDSTEIN, Wolfgang

Erdődy János-Radványi Anna ford.

(Sorozat: Pázmány könyvek, ISSN 1586-5746; 7.)

Harmadik kiadás. Szent István Társulat, Budapest, 2017

Monográfia. Terjedelem: 238. Bibliográfia a lábjegyzetekben.

ISBN 9789632773070

- A 2012-es első kiadás változatlan utánnyomása. Ismertetése a Pro Futuro 2014/2. számában. (F. F.)

\section{JOGTÖRTÉNET, RÓMAI JOG}

- A Szegedi Királyi Ítélőtábla története 1921 és 1938 között - Fejezetek a Szegedi Ítélötábla történetéből, III.

ANTAL Tamás

(Sorozat: Bíróságtörténeti Könyvek, ISSN 2064-9533)

Országos Bírósági Hivatal-Szegedi Ítélőtábla, Budapest-Szeged, 2017

Monográfia. Terjedelem: 186. Bibliográfia a végjegyzetben.

ISBN 9789631298239

- A szerző a Szegedi Tudományegyetem oktatója, munkája a Szegedi kir. Ítélőtábla történetét feldolgozó sorozat harmadik darabja. (A sorozat 2014-óta jelenik meg, eddigi köteteinek ismertetése a Pro Futuro 2016/1. és 2017/2. számában olvasható.) E kötet a két világháború közötti időszak ismertetésére vállalkozik. Három nagyobb tartalmi egységre bontható: alapos tanulmány járja körül a bíróság szervezéstörténetét a Trianon és a világgazdasági válság nyomán bekövetkezett sajátos állapotok között, az utolsó békeévekig, majd röviden néhány ünnepi eseményt és érdekesebb bírói életutat villant fel a szerző, végül öt jelentős társadalmi visszhangot is kiváltott jogeset elemző bemutatásával utal a korszak igazságszolgáltatással kapcsolatos közhangulatára. A mellékletekben és a függelékben érdekes forrásközlések, a tábla bíráinak archontológiája, és öt ítélőtábla (Szeged mellett Budapest, Debrecen, Győr és Pécs) ügyforgalmi adatainak összehasonlító táblázatai emelik a könyv értékét. (B. J.)

- Tripartitum trium professorum: három szegedi jogtörténész: tudományos emlékülés Bónis György születésének 100., Both Ödön születésének 90. és Iványi Béla halálának 50. évfordulóján

Balogh Elemér-Homoki-Nagy Mária (szerk.)

(Sorozat: A Pólay Elemér Alapítvány könyvtára, ISSN 1786-352X; 58.)

lurisperitus Kiadó, Szeged, 2017

Tanulmánykötet. Terjedelem: 344. Bibliográfia 308-341. és a lábjegyzetekben. ISBN 9786155411311 
- A kötetben szereplő tanulmányok a Bónis György születésének 100., Both Ödön születésének 90. és Iványi Béla halálának 50. évfordulója alkalmából Szegeden, 2014. november 27-28-án megrendezett tudományos emlékülés előadásainak szerkesztett változatai. A hazai és külföldi előadók emellett a Tripartitum keletkezésének 500. évfordulójáról is megemlékeztek. A német és magyar nyelvű tanulmányokat tartalmazó kötet három tematikus fejezetre tagolódik. Az első részben szereplő dolgozatok újszerủ megközelítések alapján teszik vizsgálatuk tárgyává a Hármaskönyvet. Az Institutionsgeschichte, Rechtskultur címet viselő második részben található tanulmányok témája változatos, a tanulmányok - három írás kivételével - középkori és újkori (1848 elötti) témákat dolgoznak fel. A harmadik, Professoren elnevezésű részben szereplő tanulmányok pedig a kötet címében szereplő jogtörténész professzorok életútjához, munkásságához kötődnek. Itt kapott helyet a kiadvány megjelentetése közben elhunyt Ruszoly József által készített tanulmány, és a professzor nekrológja is. (B. A.)

- Studia in honorem István Stipta

Balogh Judit-Koncz Ibolya Katalin-Szabó István-Tóth J. Zoltán (szerk.)

(Sorozat: De iuris peritorum meritis, ISSN 1789-0896; 10.)

Károli Gáspár Református Egyetem Állam- és Jogtudományi Kar, Budapest, 2017 Tanulmánykötet. Terjedelem: 490. Bibliográfia a lábjegyzetekben.

ISBN 9789639808744

- Az ünnepi kötet Stipta István professzort köszönti 65. születésnapja alkalmából; szerkesztői az ünnepelt hajdani tanítványai, legközvetlenebb kollégái. A Károli Gáspár Református Egyetem Állam- és Jogtudományi Kar jubileumi sorozatában megjelent könyvben harmincöt hazai szerző - tudatos szerkesztésben három csoport: Stipta professzor jelenlegi és volt tanítványai, kollégái és barátai - egyegy tanulmánnyal tisztelik meg az ünnepeltet. A szerzők elsősorban jogtörténészek, de más jogterületekkel foglalkozó kutatók és gyakorlati szakemberek is megtalálhatók közöttük. A tanulmányok alapvetően (jog)történeti szemléletűek, több kapcsolódik az ünnepelt valamely kutatási témájához, szakmai érdeklődéséhez. A munkák rendkívül nagy változatosságot mutatnak: a villamos energia jogi szabályozásának kezdeteitől a Csatskó Imre természetjogi nézeteit bemutató jogelméleten át a bizonyítási kötelezettség (érdek) és a bizonyítási teher fogalmi distinkcióját a hatályos polgári eljárásjogi kódex alapján értelmező tanulmányig sokféle téma megjelenik. (B. A.)

- A jászkun szabadság. A törvényesség helyi sajátosságai a Jászkun kerület népi kultúrájában (1682-1876)

BÁNKINÉ MoLnÁR Erzsébet

(Sorozat: Jogi kultúrtörténeti, jogi néprajzi kiskönyvtár, ISSN 2064 888X; 3)

Pécsi Tudományegyetem Kultúratudományi, Pedagógusképző és Vidékfejlesztési Kar, Szekszárd, 2017

Monográfia. Terjedelem: 234. Bibliográfia: 228-234. ISBN 9789634291633

- A kötet szerzője a Tárkány Szücs Ernő Jogi Kultúrtörténeti és Jogi Néprajzi Kutatócsoport alapító tagja, rangos történész, az MTA doktora. A hajdan kiváltsá- 
gos Jászkun kerület történelmének kitünő ismerője, számos jászkun-monográfia és tanulmány szerzője. E munkájában a népi jogélet néhány meghatározó aspektusát veszi számba a fennmaradt levéltári források alapján, a kerület létrejöttétől a megszüntetéséig. Az elméleti megalapozást követően a jogszokások és a kerület bíráskodásában megjelenő szokásjog főbb területei jelennek meg (földbirtok, malomtartási jog, szőlőbirtokok sorsának jogi rendezése), majd pedig a jogi szabályozás társadalmi aspektusainak felvillantása (gúnyversek és megszólás, mint társadalmi, a megszégyenítés mint egyházi szankció). Külön fejezetet kapott a jogi szimbolika is (bírói pálca, pecsét, a tized botja, billog, rováspálca, süveg). A kötetet Homoki-Nagy Mária kitűnő könyvajánlása (Előszó) és Nagy Janka Teodóra rövid utószava foglalja keretbe. A mellékletben teljes szövegközléssel megtaláljuk a kerület 1746-ban kiadott statútumát. (B. J.)

- Hatékonyság és jogbiztonság a birtokvédelmi eljárásban. Történeti, dogmatikai és jogösszehasonlító elemzések hatályos birtokvédelmi szabályozásunk elméleti és gyakorlati kérdéseihez

Béli Gábor-Jusztinger János-Pókecz Kovács Attila (szerk.)

(Sorozat: Publicationes Cathedrae luris Romani Quinqueecclesiensis,

ISSN 2064-7328; 5.)

PTE ÁJK Római Jogi Tanszék, Pécs, 2017

Konferenciakötet. Terjedelem: 132. Bibliográfia a lábjegyzetekben.

ISBN 9789634291824

- A kötet egy 2017 februárjában a Pécsi Tudományegyetemen tartott, projektzáró tudományos ülés előadásaiból kinőtt tanulmányokat tartalmazza. A könyvben található szövegek egy része csapatmunkában készült, másokat egy-egy szerző jegyez. A történeti, dogmatikai és összehasonlító elemzések mellett a hatályos szabályozás elméleti és gyakorlati tapasztalatait összegző munkák is megtalálhatók a gyűjteményben. A szerkesztők elképzelései szerint a kötet tanulmányai lehetővé teszik a birtokvédelem rendszerének komplexebb áttekintését, és elősegíthetik az egységes joggyakorlat, illetve jogértelmezés kialakulását. A publikált eredmények egyben vezérfonalul is szolgálhatnak a birtokvédelmi ügyek intézésében és elbírálásában részt vevők számára, ugyanakkor a birtokvédelmi eljárásban közremüködők szakmai továbbképzésében is hasznosíthatók. (Ú. E.)

- Sind Richter bestechlich? - Materielle Unabhängigkelt der Richter in Ungarn (1870-1920)

Beliznal Bódı, Kinga

(Sorozat: Rechtsgeschichtliche Vorträge, ISSN 1218 4942; 74)

ELTE ÁJK Magyar Állam és Jogtörténeti Tanszék, Budapest, 2017

Szaktanulmány. Terjedelem: 34. Bibliográfia a lábjegyzetekben. ISBN nincs

- A szerző az ELTE docense, aki e munkáját majdani habilitációjának témakörében jelentette meg németül. A dolgozat az 1869:IV. tc. egyik új (a rendi korszak gyakorlatával mereven szembehelyezkedő) intézményének, a bírák anyagi függetlenségének bemutatására törekszik konkrét levéltári források, és egy híressé vált per anyagának bemutatásán keresztül. A müben hangsúlyos részt kapnak a bírák 
anyagi függetlenségére vonatkozó, 20. század eleji törvényhozási javaslatok és eredmények. A tanulmány az első, 1871. évi fizetési szabályozástól - amely furcsa elveket érvényesített, hiszen eltérő mértékű volt a buda-pesti és a vidéki bírák, ellenben nem különbözött a bírák (járásbíróságok vezetői) és az albírák (azaz vezető beosztásúnak nem számító, ilyen felelősséggel nem tartozó bírák) fizetése - az 1890-es és '93-as szabályozáson keresztül, az 1903-as fizetésrendezés részletes bemutatásán keresztül ér el az 1920. évi státustörvény szabályozásáig. A szabályozástörténet bemutatását Soós Kálmán törvényszéki bíró vesztegetési ügyének részletes, elemző bemutatása egészíti ki. (B. J.)

- Római magánjog

Benedek Ferenc-Pókecz Kovács Attila

(Sorozat: Institutiones juris, ISSN 1218-9375; Dialóg Campus szakkönyvek, ISSN 1418-1274)

Ötödik, átdolgozott kiadás, Dialóg Campus, Budapest-Pécs, 2017

Egyetemi tankönyv. Terjedelem: 374. Bibliográfia a fejezetek élén.

ISBN 9786155764202

- A legutóbb 2014-ben kiadott tankönyv újabb kiadásában a bibliográfiai részek jelentősen frissültek a vonatkozó legmodernebb hazai és külföldi irodalommal. A korábbi kiadás ismertetése a Pro Futuro 2018/4. számában. (Sz. B.)

- A rejtélyes tiszaeszlári per

BLuTMAn László

Osiris, Budapest, 2017

Monográfia. Terjedelem: 511. Bibliográfia: 479-483. ISBN 9789632762937

- A szerző a Szegedi Tudományegyetem professzora, aki páratlan szakmai alapossággal vállalkozik Solymosi Eszter 1882-es eltűnésének sine ira et studio komplex jogtudományi értékelésére. A kötet az OSZK-ban elérhető eredeti forrásanyag teljes körü elemzése, a két oldal (vád: Bary J., védelem: Eötvös K.) álláspontját leíró könyvek, a korabeli sajtó és az elmúlt több mint száz évben megjelent munkák hiánytalan áttekintése, az események minden részletének kritikai szemlélete útján kíséreli meg egy objektív olvasat elkészítését. Nyomozói alapossággal vizsgál meg minden apró részletet, merül el a kor orvosszakértői ismereteiben, értelmezi a kapott véleményeket, tisztítja meg a képet a kavargó indulatoktól, és próbál alternatívákat adni az ügy megoldásához. Végül rögzíti, hogy ma sincs biztos tudásunk arról, mi történhetett Solymosi Eszterrel: valószínübb és kevésbé valószínű forgatókönyvek vannak, amelyek között szerinte a „legkevésbé valószínütlen" igen távol áll a vérvádtól - ahogyan az öngyilkosságtól is. A könyvet számos értékes összefoglaló és összehasonlító táblázat egészíti ki. (B. J.)

- A Szolnoki Törvényszék története 1945-ig Bojtos Gábor-Kelemen-Nagy Orsolya-Pongrácz Zsolt (szerk.)

Szolnoki Törvényszék, Szolnok, 2017

Tanulmánykötet. Terjedelem: 114. Bibliográfia: 109-113. ISBN 9789631288919 
- A kötet az Országos Bírósági Hivatal által támogatott bíróságtörténeti kutatások szolnoki eredményeit mutatja be. A mủ mintegy párja annak az emlékkötetnek, amely a Szolnoki Törvényszék történetét 1945-től a rendszerváltásig dolgozta fel, és 2015-ben jelent meg. A 2017-es kiadvány szerkesztői között levéltárost (Bojtos Gábor) és bírósági munkatársakat (Kelemen-Nagy Orsolya, Pongrácz Zsolt) is találunk. A szolnoki bírósági szervek történetét korabeli jogszabályok, levéltári források és a korszak sajtótermékei releváns írásainak közlésével tárja az olvasó elé. Megismerhetők ezek alapján a Szolnoki, a Jászberényi és a „Kardszagi” Királyi Törvényszékek, valamint a kapcsolódó királyi járásbíróságok megszervezésének körülményei csakúgy, mint a szolnoki igazságügyi palota épülettörténete. A könyv külön fejezetet szentel a Szolnoki Törvényszék 1885 és 1945 közötti elnökeinek, illetve a korszak sajtótermékei alapján érdekes pereket és eseteket mutat be. Az illusztrációkkal is tarkított könyv hiánypótló forrása a szolnoki jogszolgáltatás történetének. (M. P. Z.)

- Egyetemes állam- és jogtörténet

BóNIs Péter-Gönczı Katalin-STIPTA István

Patrocinium, Budapest, 2017

Tankönyv. Terjedelem: 348. Bibliográfia: nincs. ISBN 9789634131762

- A tankönyv elsősorban a Károli Gáspár Református Egyetem hallgatói részére készült. Szerzői közül ketten a kar oktatói, míg Gönczi Katalin a Szász Tudományos Akadémia kutatója. A kötet alapvetően az európai (egyetemes) állam- és jogtörténet klasszikus áttekintésére koncentrál, de a hatodik fejezetben amerikai alkotmány- és jogtörténeti kérdésekkel is foglalkozik. Nagy hangsúlyt fektet a középkori állam- és jogtörténet átfogó leírására, ezen belül pedig egy fejezetet szentel néhány jelentős magánjogi jogelv - korabeli példákkal is illusztrált - bemutatásának, amelyek hatályos jogunk müködését is alapjaiban határozzák meg (pl. pacta sunt servanda, clausula rebus sic stantibus, joggal való visszaélés tilalma), és amelyeket a korabeli jogtudomány - természetesen a római jogi alapokból kiindulva - fogalmazott meg. A kötet foglalkozik az európai integráció intézmény- és eszmetörténetének a kezdetektől a két világháború közötti időszakig történő áttekintésével is. (B. A.)

- Az alkotmány szolgálatában. Constantino Mortati élete és pályája

EGRESI Katalin

(Sorozat: Florilegium, ISSN 2498-7603; 3.)

Gondolat Kiadó, Budapest, 2017

Monográfia. Terjedelem: 181. Bibliográfia: 173-178. ISBN 9789636937447

- A szerző a győri Széchenyi István Egyetem oktatója. Jelen munkája az egyetem OTKA kutatásai keretében készült, és Olaszország 1947 végén elfogadott köztársasági alkotmánya kidolgozójának, C. Mortati professzornak állít emléket. A kötet bevezetője az olasz közjogtudomány és a modern államelméletek megszületéséröl szól, majd az alkotmány elkészítése körüli vitákat, ezt követően az alkotmány tételes rendelkezéseit ismerteti, külön figyelmet szentelve az alkotmányozási fo- 
lyamatból leszürhető tanulságoknak. A könyv második fele Mortati életmüvét mutatja be és értékeli: az egyetemi oktatót, tudós professzort, és az államelméleti felfogásokat a gyakorlati jogalkalmazásba átültető alkotmánybírót. Az olasz közjogi és politikai gondolkodás máig magán viseli a kereszténydemokrata szellemiségü Mortati hosszú és aktív munkásságának eredményeit. (B. J.)

- A római jog története és institúciói

FölDI András-HAMZA Gábor

Huszonegyedik, átdolgozott és bővített kiadás. Eszterházy Károly EgyetemOktatáskutató és Fejlesztő Intézet, Budapest, 2017

Egyetemi tankönyv. Terjedelem: 720. Bibliográfia: 26-35. és a lábjegyzetekben. ISBN 9789631979619

- A 2016-os kiadás változatlan utánnyomása. A korábbi kiadás ismertetése a Pro Futoro 2018/4. számában. (Sz. B.)

- A Szegedi Törvényszék története III. rész: Fejezetek a Szegedi Törvényszék magánjogi gyakorlatából

Homoki-NagY Mária-KRusóczkı Bence-PÉTERVÁRI Máté

Szegedi Törvényszék, Szeged, 2017

Forrásközlés (kommentálva). Terjedelem: 68. Bibliográfia a végjegyzetben. ISBN nincs

- A kiadványt az Országos Bírósági Hivatal Ráth György bírósági történelem és hagyományápolás c. pályázatán elnyert támogatással jelentette meg a Szegedi Törvényszék, a szerzők a Szegedi Tudományegyetem jogi kara Magyar Jogtörténeti Tanszékének oktatói. A Szegedi Törvényszéket érintő ítélkezéstörténeti kutatások 2014 óta folynak, jelen munkában a dualizmus időszakából és a Horthy-korszakból villantanak fel a vagyonjog három területéről származó, jellemző jogeseteket. A források feltárására csak 1890-től van lehetőség, mert a korábbi peranyagok megsemmisültek. A bemutatott peranyagok révén az olvasó képet kaphat a magánjogi peres eljárások menetéröl, különös tekintettel a bizonyítás eszközeire és azok bírói értékelésére. A perek értő bemutatása azért is különösen tanulságos, mivel a korszakban - törvénykönyv híján - a bírói joggyakorlat a jogfejlesztés egyik legfontosabb eszközévé lépett elö. (B. J.)

\section{- Forum Romanum. Jogesetek római jogból}

JAKAB Éva

Nyolcadik, átdolgozott kiadás. Leges Bt., Szeged, 2017

Tansegédlet. Terjedelem: 161. ISBN 9786158077705

- Az első alkalommal 2002-ben megjelent, akkor még szerződési mintákat is tartalmazó római jogi tansegédlet, a 2012-es hetedik kiadáshoz képest jelentősen átdolgozott nyolcadik kiadása. A kötetben a római jogi tananyag rendszerében a Digestából vett jogtudósi responsumokra alapozva nyerhetnek bepillantást a gyakorlati órákat látogató joghallgatók a római jog „igazi világába”. Az összeállító szegedi professzor célja, hogy az eredeti források tanulmányozása révén a hallgatók közvetlenül ismerjék meg a római jogászok gondolkodási és argumentálási technikáit, ezáltal új nézőpontból mélyülhessenek el a római jog későbbi tanulmá- 
nyaik számára is hasznos anyagában. A hallgatóbarát kötet praktikus segítséget is nyújt a vizsgára való felkészüléshez egyes gyakori kérdések felvillantásával és a legfontosabb alapfogalmak tisztázásával. Egy korábbi kiadás annotációja a Pro Futuro 2012/1. számában. (Sz. B.)

- Tanulmányok az új Ptk. egyes szerződéseinek római jogi alapjai köréből Jusztinger János-Pókecz Kovács Attila (szerk.)

(Sorozat: Institutiones juris, ISSN 1218-9375; Dialóg Campus szakkönyvek, ISSN 1417-7986)

Dialóg Campus, Budapest-Pécs, 2017

Tanulmánykötet. Terjedelem: 159. Bibliográfia: 7-8. és a lábjegyzetekben. ISBN 9786155764066

- A Pécsi Tudományegyetem Római Jogi Tanszéke három oktatójának (Pókecz Kovács Attila, Jusztinger János, Csoknya Tünde Éva) tollából származik a tanulmánykötet hét tanulmánya, amelyek évezredes jogfejlődést áthidalva mutatják ki a kapcsolatot az új Ptk. egyes szerződései (használati típusú szerződések, adásvételi általános szabályok, letét és vállalkozási szerződés) és a római jog vonatkozó megoldásai között. Az adott szerződéscsoportok romanista szakértőiként a tanulmányok szerzői jelentős mértékben hozzájárulnak a magánjogi megoldások kontinuitásának felismeréséhez, munkájuk ösztönözheti a párbeszéd megélénkülését a romanisztika és a civilisztika képviselői között. A tanulmányok joggal sorolhatók a Nyugat-Európában elfogadott magánjogtörténeti kutatási irányzat körébe. (Sz. B.)

- Források a kivételes hatalom szabályozásának magyarországi geneziséről Kelemen Roland (szerk.)

Magyar Katonai Jogi és Hadijogi Társaság, Budapest, 2017

Tanulmány és forrásközlés. Terjedelem: 217. Bibliográfia a lábjegyzetekben. ISBN 9789631290929

- A szerző a győri Széchenyi István Egyetem oktatója, a magyar jogtörténet különös területeinek, a hadijog és a kivételes jogrend történetének elismert, termékeny kutatója. A kötet bevezetését egy alapos tanulmány adja, amelyben a szerző a kivételes hatalomról szóló első magyar törvény, az 1912. évi LXIII. törvény előkészületeit, országgyűlési tárgyalását, szakirodalmi és sajtóvisszhangját ismerteti. Az elemzésben kitér a dualizmus, különösen az utolsó békeévek közjogi és büntető eljárásjogi szabályainak azon rendelkezéseire, amelyek lehetővé tették a kivételes felhatalmazás valamilyen formáját. A könyv további részében a tanulmány alapjául szolgáló forrásokból közöl válogatást a szerző. Megismerhetjük az eredeti törvényjavaslatot, az országgyúlés Igazságügyi Bizottságának erről formált jelentését, a képviselőházi és förendiházi tárgyalások jegyzőkönyveit, valamint a hírlapokban megjelent jó néhány sajtótudósítást. (B. J.) 
- Ünnepi tanulmányok Máthé Gábor oktatói pályafutásának 50. jubileumára: studia sollemnia scientiarum politico-cameralium

Kis Norbert-Peres Zsuzsanna (szerk.)

Dialóg Campus, Budapest, 2017

Tanulmánykötet. Terjedelem: 454. Bibliográfia a lábjegyzetekben.

ISBN 9786155764684

- A Máthé Gábor professzor oktatói pályafutásának 50. évfordulójára kiadott tanulmánykötetbe az ünnepelt negyvenkét kollégája, tanítványa, barátja készített egy-egy írást, ezzel tisztelegve a jogtörténet doyenje előtt. A szerzők elsősorban a hazai egyetemek jogtörténeti tanszékeinek oktatói, a tételes jog művelöi és a társadalomtudományok kutatói. Ennek megfelelően a tanulmányok rendkívül változatos képet mutatnak mind a kutatott jogterületek, mind a vizsgált korszakok vonatkozásában. Találkozunk alkotmány-, közigazgatási, büntető- és magánjogtörténeti munkákkal is, amelyek nagy része magyar kötődésü, de e liber amicorumban az angol esküdtszék szabályozásában a 19-20. században bekövetkezett változások áttekintéséről, az 1849. évi dán alkotmányról vagy az amerikai alelnöki szukcessziók történetéröl is lehet olvasni. (B. A.)

\section{- Die Entwicklung der Verfassung und des Rechts in Ungarn}

Máthé Gábor (szerk.)

Dialóg Campus, Budapest, 2017

Kézikönyv. Terjedelem: 998. Bibliográfia a fejezetek végén.

ISBN 9786155680915

- A hiánypótló munka szerzői kivétel nélkül egyetemi oktatók. A kötet a magyar alkotmány- és jogtörténet föbb intézményeinek széles körü, európai megismertetését célozza. Kiindulópontja a szerkesztő, Máthé Gábor professzor 2014-ben kezdett szervezőmunkája, amelyben a hazai jogtörténeti tanszékek vezetőit kérte fel a kutatási területeikhez illeszkedő, magyar nyelvű tanulmányok elkészítésére. A munka aztán kiegészült néhány további egyetemi oktató tanulmányaival, akik szükebb szakterületükről írtak egy-egy fejezetet (például Antal Tamás a polgári kor büntetőeljárási jogáról és az esküdtbíráskodásról). Az 1945-től a rendszerváltásig terjedő időszakot tárgyaló, IV. fejezetben a hatályos jog professzorainak (Kukorelli István, Harmathy Attila, Király Tibor, Varga Zs. András) írásait olvashatjuk. A kötet szerkezete a magyar alkotmány- és jogtörténet általánosan elfogadott, egyetemi oktatási tematikájához igazodik. A könyv fejezeteit három szakfordító ültette át német nyelvre. (B. J.)

- A jogszolgáltatás története Berettyóújfaluban

Megyeri-Pálfi Zoltán (szerk.)

Debreceni Törvényszék, Debrecen, 2017

Tanulmánykötet. Terjedelem: 120. Bibliográfia a tanulmányok végén.

ISBN 9789631286038

- A kötet a Debreceni Törvényszék, a Hajdú-Bihar Megyei Levéltár és a Debreceni Egyetem ÁJK Jogtörténeti Tanszéke által gondozott bíróságtörténeti könyvsorozat második darabjaként jelent meg, a modern bírósági szervezetrendszer 
létrejöttének 145. évfordulója alkalmából megrendezett konferencia és kiállítás tíz tanulmányával. A muzeológusokból, levéltárosokból és egyetemi kutatókból álló szerzői közösség tanulmányai Berettyóújfalu jogszolgáltatásának (és jogéletének) lenyomatait tárják az olvasó elé. A kötetben szereplő bíróságtörténeti írások a rendi korból Bihar vármegye törvényszékének, a polgári korszakból pedig a Berettyóújfalui m. kir. Járásbíróságnak a történetét tekintik át. Emellett vázlatos képet kapunk a település történetéröl, olvashatunk a járásbíróság épülete(i)ről és azok átalakításairól, valamint a járásbíróság utolsó elnökének példaértékű életútjáról. A kötetben szereplő archontológia képet ad a hajdani járásbíróság személyzetéről, valamint két tanulmányban a Bihar vármegyéhez kapcsolódó érdekes jogesetek irodalmi vetületei találhatók. (B. A.)

\section{- Die Auswirkungen politisch-sozialer Umbrüche auf das Strafrecht}

Mezey Barna (szerk.)

(Sorozat: Rechtsgeschichtliche Vorträge, ISSN 1218 4942; 73.)

Eötvös Loránd Tudományegyetem Magyar Állam- és Jogtörténeti Tanszék, Budapest, 2017

Tanulmánykötet. Terjedelem: 113. Bibliográfia a lábjegyzetekben. ISBN nincs

- A magyar szerzők az ELTE Magyar Állam- és Jogtörténeti tanszékéhez kötődő kutatók, német oldalról pedig az Augsburgi Egyetem büntetőjogász profeszszora és Németország talán legjelentősebb börtönmúzeumának, a rothenburgi Mittelalterliches Kriminalmuseumnak egy jogtörténész munkatársa. A kötet a 2000 ben Günter Jerouschek és Mezey Barna professzorok által létrehozott, németmagyar büntetőjogi szeminárium 2017-es, Szombathelyen tartott rendezvényéhez kapcsolódó, kilenc tanulmányt tartalmaz. A szeminárium fö témája a reformáció tanainak a büntetőjog fejlődésére gyakorolt hatása volt, e körben különösen a munkabüntetések megjelenése, a szabadságelvonás megítélésének változásai, a börtönügyi helyzet és az elítéltek jogairól vallott felfogások kerültek napirendre a kora középkortól a második világháború utáni kollektív bünösségi felfogásig. Különösen a német szerzők tanulmányai tartalmaznak a lábjegyzetekben bőséges szakirodalmi utalást, amellyel a további kutatásokat segíthetik. (B. J.)

- Dologi hitelbiztosítékok az ügyleti gyakorlatban. Kauteláris praxis a préklasszikus és klasszikus korszakban

Pozsonyı Norbert

(Sorozat: A Pólay Elemér Alapítvány Könyvtára, ISSN 1786-352X; 66.) lurisperitus, Szeged, 2017 Monográfia. Terjedelem 200. Bibliográfia: 181-197. ISBN 9786155411687

- A Pólay Alapítvány igényes könyvsorozatának kiadványaként a szerző a 2012-ben megvédett doktori disszertációjának részben átdolgozott változatát adja az olvasó kezébe. A munka epigráfiai és ókori - nem jogi - források segítségével (persze nem elhanyagolva a jogi forrásokat sem) a korabeli okirati gyakorlaton keresztül kíván közelebb vinni az akkori mindennapok jogéletéhez és joggyakorlatához, a kötelmi követelések biztosítása céljára rendelt dologi garanciák terén. Tucatnyi dokumentum köré csoportosítja mondanivalóját, bemutatva azt a speciális fejlő- 
dési folyamatot, amelynek eredményeként a szerződési gyakorlatban gyökerező zálogjogi megoldások a diszpozitív jog elterjedt részévé váltak. A vizsgált (a Kr. e. II. és a Kr. u. II. század közötti időszakból származó) szövegeket, zálogklauzulákat nem választja el a gazdasági és jogi kontextus elemzésétől: kifejezetten törekszik arra, hogy minél teljesebb képet alkosson az ügyleti és jogi környezetröl is, amelyben az egyes zálogkikötések megjelentek. (Sz. B.)

\section{- Magyar közjegyzők a Délvidéken}

RokOLYA Gábor

(Sorozat: Studia Notarialia Hungarica Tom. XXIII, ISSN 1416-5635)

Közjegyzői Akadémiai Kiadó, Budapest, 2017

Monográfia. Terjedelem: 587. Bibliográfia: 528-559. és a végjegyzetekben. ISBN 9786158017688

- A szerző gyakorló közjegyző, egyben a közjegyzőség történetének szakavatott kutatója: számos, a közjegyzői intézménnyel foglalkozó kötet szerzője és szerkesztője. A korábbi, a közjegyzőség átfogó történetét bemutató monográfiák után e munkája más szemlélettel készült: egy behatárolható földrajzi térség, a Délvidék közjegyzőiről készített történeti feldolgozást. A könyv elkészítésével célja a térség nemzetiségi, gazdasági viszonyainak ismertetése, ezzel összefüggésben a közjegyzői ügyforgalom elemző feldolgozása volt. Mindemellett a monográfia az igazságügy területén megvalósuló nemzetiségi nyelvhasználat érvényesülését is bemutatja, statisztikai és térképészeti adatok figyelembevételével. A gazdagon illusztrált és adatolt kötet két részre oszlik: elsőként a délvidéki közjegyzői szervezetekröl és a kisebbségi nyelvhasználatról szól, amely mellett figyelmet szentel a térség közjegyzőinek alkotói munkásságára is; a második részben pedig az egyes közjegyzői hivatalok történetét és közjegyzőit mutatja be, a törvényszéki beosztást követve. (M. P. Z.)

- A bizalmi vagyonkezelés és a trust

SÁNDOR István

HVG-ORAC Kiadó, Budapest, 2017

Monográfia. Terjedelem: 555. Bibliográfia: 469-511. ISBN 9789632583242

- A szerző egyetemi docens (ELTE és KRE) és gyakorló ügyvéd, akinek munkája - a 2014-es első kiadás után (ismertetése a Pro Futuro 2016/1. számában) jelentősen kibővítve - jelent meg. 2019 decemberében e könyv alapján szerezte meg a szerző az MTA doktora címet. A második kiadás újdonsága, hogy abban jelentősen kibővült a trust típusait bemutató $V$. fejezet tartalma: új, részletesebb csoportosításban ismerteti az európai államok közül az angolszász modellen alapuló, a német Treuhand-típusú, a francia fiducie modellt követö, majd a különleges megoldásokat alkalmazó államok szabályozását, majd egy csokorba gyűjti az észak- (lett, litván) és kelet-európai államok szabályait. Az új kiadásban a szerző kissé átalakította és bővítette a magyar szabályozás ismertetését is. (B. J.) 
- A Magyar Királyi Köztársaságtól a Magyar Köztársaságig. Közjog- és tudománytörténeti tanulmányok

SCHWEITZER Gábor

Publikon Kiadó, Pécs, 2017

Tanulmánykötet. Terjedelem: 153. Bibliográfia a lábjegyzetekben.

ISBN 9786155457814

- A szerző közjogász, az MTA TK Jogtudományi Intézetének kutatója, egyetemi oktató. E kötetében 2012-2017 között már megjelent hat munka, továbbá egy új dolgozat kapott helyet. A tanulmányokban elsősorban a két világháború közötti Magyarország közjogi berendezkedését értelmezi, áttekintést nyújt a korabeli közjogtudomány egészéről, annak teoretikus és gyakorlati oldalát is megvizsgálva. Két hosszabb tanulmány a két világháború közötti szabadságjogok szabályozásával foglalkozik. A kötet utolsó harmadát az 1945 utáni időszaknak szenteli. A jogforrási besorolás, a köztársasági államformáról alkotott vélemény és a preambulumban szereplő szabadságjogok értékelése útján mutatja be a Ruszoly József által „kisalkotmánynak” nevezett 1946:I. tc. szakirodalmi visszhangját, majd a 2012. január 1. napjával hatályba lépett Alaptörvényt a történeti/történelmi alkotmány fényében közelíti meg, felmutatva az 1949-es alkotmányhoz, és a jelenlegi Alaptörvényhez is köthetö, historizáló kísérleteket. (B. J.)

\section{- A ius offerendi problematikája a római magánjogban}

SIKLÓsı Iván

(Sorozat: ELTE jogi kari tudomány, ISSN 2060 9361; 39.)

ELTE Eötvös Kiadó, Budapest, 2017

Monográfia. Terjedelem: 224. Bibliográfia: 207-213. ISBN 9789633122839

- A szerző az Eötvös Loránd Tudományegyetem Római Jogi és Összehasonlító Jogtörténeti Tanszékének oktatója, immár harmadik monográfiájával jelentkezik a római magánjog területéröl. A munka a római zálogjog egyik fontos részletkérdését, a többszörös elzálogosítás kapcsán felmerülö ius offerendinek, a záloghelymegváltás lehetőségének császárkori konstrukcióját vizsgálja a külföldi szakirodalom vonatkozásában is elismerésre méltó alapossággal. A releváns források elemzése mellett a szakirodalmi értelmezések ütköztetésével kísérel meg önálló választ adni a ius offerendivel kapcsolatos nyitott kérdésekre, kitérve a konstrukció továbbélésére is. (Ú. E.)

- Győr vármegye főispánjai

Torma Attila

Dr. Kovács Pál Megyei Könyvtár és Közösségi Tér-Szülöföldünk Györ-MosonSopron Megyei Honismereti Egyesület, Győr, 2017 Monográfia. Terjedelem: 491. Bibliográfia a jegyzetekben. ISBN 9786158057134

- A szerző nyugalmazott középiskolai tanár, a helytörténet ismert és elismert kutatója, akinek Györ történetéhez kapcsolódóan ez már a negyedik önálló könyve. Az alapvetően helytörténeti munka jogtudományi érdekességét az adja, hogy a főispáni tisztséget betöltő személyek életrajzai mellett (a kötet bevezető tanulmányában) a szerző részletezi a közigazgatás-történeti vonatkozásokat is. Tanul- 
mányai kronologikus rendben követik egymást, 27 föispán teljességre törekvően feltárt életrajzát olvashatjuk. Forrásként a levéltári anyagokat, a korabeli sajtó teljes állományát és (az általa felkutatott családi vonatkozások révén) személyes emlékeket használt fel. A föispánok között több, később országos jelentőségűvé emelkedett politikust is találunk (pl. Darányi Kálmán és gr. Khuen-Héderváry Károly későbbi miniszterelnököket, gr. Batthyány Lajost, a későbbi fiumei kormányzót, vagy Huszár Aladárt, Budapest későbbi főpolgármesterét). (B. J.)

- Szokás és szabadság. Tanulmányok a középkori magyar jogszokások és kiváltságok történetéhez

TRINGLI István

Line Design Kiadó, Budapest, 2017

Tanulmánykötet. Terjedelem: 239. Bibliográfia a jegyzetekben.

ISBN 9789634800002

- A szerző az ELTE és a Szegedi Tudományegyetem magyar középkorral foglalkozó történésze. E munkáját jogászszemmel azért különösen érdekes olvasni, mivel feltett szándéka, hogy a köztörténet és a jogtörténet művelöit közös munkára serkentse, hiszen - a föképp fogalomhasználati különbségek ellenére - a két területen dolgozóknak szükségképpen fel kell használniuk egymás eredményeit, a két megközelítés kiegészíti egymást (már csak azért is, mert napjaink jogtörténet-tudománya - Béli Gábor jeles munkásságát ide nem értve - önállóan szinte képtelen a kora-középkor eredeti források feldolgozásán alapuló értelmezésére). A kötetben 12 (korábban már megjelent) tanulmány kapott helyet, amelyeket egy - a korábbi írásaira érkezett kritikai észrevételekre reflektáló - új munkával egészített ki a szerző. A jogtörténeti szempontból legizgalmasabb részek a megyei közgyülések bíráskodási gyakorlatával, a korai peres eljárással, a szent (és „boldogult") királyokra való hivatkozás legitimáló hatásával, valamint a városi szabadságokkal foglalkoznak. (B. J.)

\section{MUNKAJOG}

- Kommentár a munka törvénykönyvéhez: Kommentár a munka törvénykönyvéröl szóló 2012. évi l. törvényhez

BANKó Zoltán-Berke Gyula-KAJTÁR Edit-Kıss György-Kovács Erika Harmadik, átdolgozott kiadás. Wolters Kluwer, Budapest, 2017 Kommentár. Terjedelem: 842. Bibliográfia: nincs. ISBN 9789632956749

- A korábbi kiadások átdolgozására a hazai és az európai uniós szintű szabályozás változására és a bírói gyakorlat alakulására figyelemmel került sor. Az első és második kiadás annotációját lásd a Pro Futuro 2014/1., illetve a 2016/1. számában. (K. G. Á.)

- A közalkalmazottak jogállásáról szóló törvény és magyarázata CsÉFFÁn József

152 Szegedi Rendezvényszervező Kft., Szeged, 2017 Kommentár. Terjedelem: 1003. Bibliográfia nincs. ISBN 9786155112140 
- A korábbi kiadás átdolgozására a Munka Törvénykönyvéröl szóló 2012. évi I. törvény 2017. január 1-jétöl hatályba lépett változásaira figyelemmel került sor. A korábbi kiadás annotációja a Pro Futuro 2018/2. lapszámában olvasható. (S. M.)

- A közjegyzők jogállása, szervezete, valamint tevékenységének alapjai, különös figyelemmel az egyes közjegyzői nemperes eljárásokra

FERENCZI Fanni

Debreceni Egyetemi Kiadó, Debrecen, 2017

Monográfia. Terjedelem: 136. Bibliográfia 121-136. és a lábjegyzetekben.

ISBN 9789633186268

- A szerző debreceni székhelyű közjegyző. A mű a közjegyzői státusszal, valamint feladatokkal kapcsolatos, teljes körü képet kíván nyújtani. A monográfia érinti - többek között - a jogállás alapvető kérdéseit, a szervezeti kereteket, a közjegyző feladat- és hatásköreit. A szerző múvében igen alaposan mutatja be a - statikus elemek mellett - a különböző eljárásokat, feltárva azok természetét, jogszabályi háttereit. A szerző szándékát - miszerint egy átfogó képet kíván adni a közjegyzőségröl - maradéktalanul teljesíti. (K. G. Á.)

- Munkajog

Gyulavári Tamás (szerk.)

(Sorozat: ELTE Jogi Kari Tankönyvek, ISSN 2060-6494; 7.)

Harmadik, átdolgozott kiadás. ELTE Eötvös, Budapest, 2017

Tankönyv. Terjedelem: 578 . Bibliográfia a fejezetek végén és a lábjegyzetekben. ISBN 9789633122075

- A korábbi kiadások annotációja a Pro Futuro 2015/1., 2016/2. és 2018/2. számában olvasható. (S. M.)

- Társadalombiztositási jog: jogi szakvizsga felkészítö kötet

Homıcskó Árpád Olivér

(Sorozat: Jogi Szakvizsga Könyvek)

Második kiadás. Patrocinium, Budapest, 2017

Tansegédlet. Terjedelem: 240. Bibliográfia nincs. ISBN 9789634131533

- A mü első kiadása a Pro Futuro 2018/2. lapszámában annotálásra került. (K. G. Á.)

- Bevezetés a társadalombiztositási jogba

Hajdú József-Homicskó Árpád Olivér (szerk.)

(Sorozat: Bethlen-sorozat, ISSN 2062-2546)

Ötödik, jelentősen átdolgozott kiadás. Patrocinium, Budapest, 2017

Tankönyv. Terjedelem: 246. Bibliográfia a lábjegyzetekben és a fejezetek végén. ISBN 978-963-413-156-4

A szerzők egyetemi oktatók, kutatók, emellett gyakorló jogászok. A tankönyv a jogászképzésben részt vevő hallgatók számára készült, ám egyúttal a joggyakorlat számára is hasznos, a jogalkalmazást megkönnyítő rendszerező, jogi szabályozást bemutató kézikönyvként is használható. A hazai jogi környezet bemutatása mellett kitérnek a szerzők a társadalombiztosítás szempontjából irányadó 
nemzetközi szabályozás ismertetésére is. A könyvben részletes elemzésre kerül a 2017. március 31-ig hatályos időállapot szerint a magyar szociális és társadalombiztosítási ellátórendszer, az egészség- és nyugdíjbiztosítás alapvető szabályai. A korábbi kiadásokat a Pro Futuro 2015/2. és 2017/2. számában annotáltuk. (K. G. Á.)

- Társadalombiztositási és szociálpolitikai alapismeretek Homıcskó Árpád Olivér Második, átdolgozott kiadás. Patrocinium, Budapest, 2017 Egyetemi jegyzet. Terjedelem: 228. Bibliográfia a lábjegyzetekben. ISBN 9789634131540

- A szerző a Károli Gáspár Református Egyetem oktatója és kutatója, valamint gyakorló jogász. A tansegédlet a jogi asszisztens képzésben részt vevő hallgatók számára készült, így összefoglaló jelleggel mutatja be a magyar szociális és társadalombiztosítási ellátórendszert, kitér az egészség- és nyugdíjbiztosítás alapvető szabályaira, a foglalkoztatáspolitika támogatási rendszerére, valamint a szociális igazgatás és ellátás egyes kérdéseire. (S. M.)

- Szociális jog II.: Tananyag a társadalombiztositási és szociális ellátások megismeréséhez

Homıcskó Árpád Olivér

(Sorozat: Bethlen-sorozat, ISSN 2062-2546)

Második, átdolgozott kiadás. Patrocinium, Budapest, 2017

Egyetemi jegyzet. Terjedelem: 230. Bibliográfia nincs. ISBN 9789634132295

- A szerző a Károli Gáspár Református Egyetem oktatója és kutatója, valamint gyakorló jogász. A mű a szociális jog kötelékébe tartozó, szerteágazó jogintézmények hátterét kívánja górcső alá venni, részletes elemzést adva - többek között a magyar szociális ellátórendszer fejlődéséről, az egészség- és nyugdíjbiztosításról, foglalkoztatáspolitikai támogatásokról, szociális igazgatás és ellátás egyes kérdéseiről, családtámogatási ellátásokról, illetve fogyatékos személyek jogairól. (S. M.)

- Egészségügyi és szociális jogi kézikönyv

Kovács Gábor (szerk.)

Universitas-Győr Nonprofit Kft., Győr, 2017

Kézikönyv. Terjedelem: 342. Bibliográfia: 343-344. ISBN 9786155298981

- A szerző a győri Széchenyi Egyetem tanszékvezető egyetemi tanára. Művében két jelentősebb jogi témakör, nevezetesen az egészségügyi jog és a társadalombiztosítási jog feldolgozására vállalkozott. Tekintettel arra, hogy a szerző orvostudományi és állam- és jogtudományi végzettséggel is rendelkezik, így a tárgyalt témakörök a vártnál jóval részletesebben, alaposabban, és mindkét szakmai terület kihívásainak megfelelően kerülnek bemutatásra. E közel 350 oldalas könyv mind a szakmai közönség, mind a téma iránt figyelemmel viseltető laikusok számára hasznos olvasmány. (K. G. Á.) 
- A munkaviszony megszünése és megszüntetése

LÖRINCZ György

HVG-ORAC, Budapest, 2017

Monográfia. Terjedelem: 374. Bibliográfia nincs. ISBN 9789632583297

- A szerző ügyvéd. A kötet célja, hogy teljeskörüen bemutassa a munkaviszony megszünésére és megszüntetésére vonatkozó, hatályos jogi szabályozást, úgy, hogy az elméleti alapok mellett a releváns bírói gyakorlat is megjelenik. A könyv tizenhárom különálló fejezete kellő részletességgel taglalja a munkaviszony megszünésének, megszüntetésének eseteit, kitérve a csoportos létszámcsökkentés kérdéskörére, a vezető állású munkavállalók jogi helyzetére, valamint a jogellenes jogviszony-megszüntetésre. A kötet zárófejezete részletes iratmintákat tartalmaz. (K. G. Á.)

- A vezető tisztségviselő jogállása és felelőssége

Pál Lajos (szerk.)

HVG-ORAC, Budapest, 2017

Tanulmánykötet. Terjedelem: 216. Bibliográfia lábjegyzetekben.

ISBN 9789632583433

- A tanulmánykötet szerzői - tizenhat gyakorló jogász és egyetemi oktató, kutató azon anomália feloldására vállalkoztak, hogy a vezető tisztségviselő jogállásának alapvető kérdéseit többféle nézőpontból elemezzék. A szerzők érintik - többek között - az egyes felelősségi kérdéseket, az alkalmazandó jogszabály kérdéseit, a vezető tisztségviselő pozíciójával kapcsolatos jogviszony tartalmi elemeit, a belső és külső kárfelelősséget. A kötet ezen túl elvégzi a tisztség szabályozásának összehasonlító jogi vizsgálatát is, megvilágítja a külföldi jogrendszerekben megjelenő sajátosságait. Az új Ptk. hatálybalépésével e státusz kérdése és az azzal kapcsolatos viták új életre kaptak, amelyek folytatásához nagymértékben hozzájárul e könyv. (S. M.)

\section{POLGÁRI JOG, POLGÁRI ELJÁRÁSJOG ÉS NEMZETKÖZI MAGÁNJOG}

- A magyar család jogi rendje

BARzó Tímea

Patrocinium, Budapest, 2017

Monográfia. Terjedelem: 565. Bibliográfia: 556-564. ISBN 9789634131779

- A szerző egyetemi oktató. A magyar családjog ilyen átfogó jellegű feldolgozására a hazai szakirodalomban eddig még nem került sor. Ezért a kötet a jogterület teljes körü bemutatásával, az elméleti és gyakorlati kérdések vizsgálatával, hiánypótlónak tekinthető. A szerző munkáját öt részre osztja, és a 2013. évi V. törvény (Ptk.) Negyedik Könyvének (Családjog) szerkezete szerint haladva mutatja be részletesen az egyes jogintézményeket. A rendszertani alapok és az alapelvek ismertetését követően a házasság, a bejegyzett élettársi kapcsolat és a de facto élettársi viszony, a rokonság és a gyámság intézményeinek részletszabályait 
tárgyalja, nemzetközi és történeti kitekintéssel kiegészítve. Ismerteti az elvi jelentőségủ bírói döntéseket és a gyámhatósági gyakorlatot is, és ezek alapján (többször kritikusan) értelmezi az új Ptk. szabályait. (T. F.)

- A versenyképesség jogi kérdései 2017-ben. Tanulmányok a gazdasági jog köréből. Kutatások a Budapesti Corvinus Egyetemen

Bodzási Balázs (szerk.)

HVG-ORAC, Budapest, 2017

Tanulmánykötet. Terjedelem: 314. Bibliográfia a lábjegyzetekben.

ISBN 9789632583327

- A kötetben a Budapesti Corvinus Egyetem oktatóinak írásai mellett, a Magyar Nemzeti Bank munkatársaitól, valamint a gazdasági joggal foglalkozó bíráktól, ügyvédektöl és vállalati jogtanácsosoktól is olvashatóak tanulmányok. A BCE Pénzügyi és Gazdasági Központ keretében a 2016-17-es periódusban megvalósult kutatások tárgya Magyarország versenyképességének javítása volt. Ennek megfelelően a tanulmányok elsősorban arra fókuszálnak, hogy a magyar normatív szabályozásnak melyek azok a területei, amelyek fejlesztésre szorulnak a versenyképesség javítása érdekében. Így olvashatunk az új választottbírósági törvényről, a befektetővédelemről és tőkepiaci szabályozásról, de olyan írások is színesítik a tanulmánykötetet, amelyek a nem-teljesítő, illetve a késedelmes hitelekhez kapcsolódó kérdéseket feszegetik. (B. S.)

- Polgári jog és eljárásjog a gyakorlatban. Iratminták a jogi szakvizsga „A” modul írásbeli vizsgájához

Boóc Ádám-Stubenvoll Zsolt

(Sorozat: Jogi szakvizsga könyvek)

Patrocinium, Budapest, 2017

Iratmintatár. Terjedelem: 354. Bibliográfia nincs. ISBN 9789634131571

- Boóc Ádám a Károli Gáspár Református Egyetem oktatója, ügyvéd, Stubenvoll Zsolt ügyvéd. Az elsősorban a szakvizsgázók számára készült könyvben a szerzők - a jogi szakvizsga tételsorához igazodva - 31 jogterületet mutatnak be a joggyakorlatban előforduló iratokhoz szerkesztett mintákon keresztül. Hasznos és ajánlott forrásanyag lehet azoknak is, akik egyetemi tanulmányaik befejezését követően munkájuk során gyakorlatszerzés végett ismerkednek a polgári anyagi jogi és eljárásjogi iratminták készítésével. (Sze. B.)

\section{- Nemzetközi magánjog}

Burián László-Raffal Katalin-Szabó Sarolta

(Sorozat: Pázmány Péter Katolikus Egyetem Jog- és Államtudományi Karának tankönyvei, ISSN 2062-0837)

Pázmány Press, Budapest, 2017

Tankönyv. Terjedelem: 484. Bibliográfia az egyes fejezetek végén.

ISBN 9789633083208

- A szerzők a PPKE JÁK Nemzetközi Magánjogi Tanszékének oktatói. A kötet a nemzetközi magánjogról szóló 2017. évi XXVIII. törvény és annak indokolása alapján 
készült. Az előző évben önálló kötetként megjelent Általános Rész korábbi hét fejezete kilenc fejezetre bővült. A nemzetközi magánjog alapkérdései, fogalma, forrásai, a történeti aspektusok, kollíziós szabályok mellett immár külön szerkezeti egységet képez egyrészt a külföldi jog alkalmazása, másrészt a közrendi záradék és imperatív szabályok. A Különös Rész fejezetei a személyi, család-, élettársi, dologi, kötelmi, öröklési jogi, illetve a joghatósági szabályokat tartalmazzák. Ezeket a kapcsolódó nemzetközi szerződések és az uniós joganyag listáit tartalmazó függelék egészíti ki. Az Általános Rész korábbi két kiadásának annotációja a Pro Futuro 2016/1. és 2018/2. számában olvasható. (F. B.)

- Gazdasági társaságok átalakulása. Jogi háttér - számvitel - adózás

EgRI-RETEZI Katalin-EgRI István Iván

(Sorozat: Vezinfó-tudástár, ISSN 2061-4780)

VEZINFÓ, Budapest, 2017

Kézikönyv. Terjedelem: 268. Bibliográfia nincs. ISBN 9786155085505

- A szerzők könyvvizsgálók és adószakértők. A könyv - követve a jogszabályi változásokat - megkísérli összefoglalni a gazdasági társaságok legfontosabb szabályait. Az átalakuláshoz kapcsolódó jogi hátteret, számviteli kérdéseket, valamint az átalakulás adó- és köztehervonzatait mutatja be. A kötetben számos táblázat és magyarázó ábra található. A melléklet okiratmintákat tartalmaz, több forgatókönyvről, átalakulási tervröl, cégbejegyzési kérelemről és vagyonleltárról. A jogi és pénzügyi vonatkozások miatt mindkét szakma képviselói számára érdekes lehet, valamint azok számára is, akiknek gazdasági társaság tagjaiként kell rendelkezniük a gazdasági társaságok szabályozásával kapcsolatos ismeretekkel. (G. B.)

- Kötelmi jog: Általános rész

FazeKas Judit-MenYHÁRT Ádám-KöHID Ákos

Gondolat, Budapest, 2017

Tankönyv. Terjedelem: 296. Bibliográfia: 295-296. ISBN 9789636937768

- A szerzők a győri Széchenyi István Egyetem jogi karának oktatói. A kötet három fő részből áll, amelyek a Ptk. VI. könyvének fejezeteit követik. Az első a kötelmek közös, a második a szerződési jog általános, a harmadik pedig a szerződésen kívüli károkozás szabályait mutatja be. A típusszerződésekre vonatkozó különös szabályokat nem tartalmazza, figyelemmel arra, hogy azokat a szerzők külön kötetben kívánják feldolgozni. A tankönyv fogalommeghatározások, magyarázatok, bírósági ítéletek, határozatok és példák mentén ismerteti meg az olvasóval a kötelmi jog általános részét. Elsősorban a joghallgatók számára nyújt segítséget, hiszen az egyetemi elöadások kibővített anyagát tartalmazza, de a szakmai közönség és más szakok kötelmi jogot tanuló hallgatói számára is hasznos lehet. (G. B.)

\section{- Jogi személyek a gazdasági forgalomban}

FÉzer Tamás-Károlyı Géza-PetKó Mihály-Törö Emese

Magánkiadás. Debrecen, 2017

Egyetemi jegyzet. Terjedelem: 390. Bibliográfia: 389-390.

ISBN 9789630891066 
- A szerzők a Debreceni Egyetem oktatói, akik a kereskedelmi jog oktatásában vesznek részt. $A z$ intézmény repozitóriumában szabadon elérhető könyv célja, hogy - a tárgy tematikájához igazodva - átfogó képet adjon a kereskedelmi jog és a gazdasági élet szereplőire (természetes személyekre, gazdasági társaságokra, a nonprofit szervezetekre) vonatkozó hatályos magyar joganyagról, valamint a kapcsolódó uniós társasági jogi és versenyjogi normákról. Külön fejezetek tárgyalják a gazdálkodó szervezetek nyilvántartásával, átalakulásával, megszünésével, az adósságrendezéssel kapcsolatos eljárásokat. (B. E.)

- Lege duce, comite familia. Ünnepi tanulmányok Tóthné Fábián Eszter tiszteletére, jogászi pályafutásának 60. évfordulójára

Görög Márta-Hegedűs Andrea (szerk.)

(Sorozat: A Pólay Elemér Alapítvány könyvtára, ISSN 1786-352X; 68.)

lurisperitius, Szeged, 2017

Tanulmánykötet. Terjedelem: 536. Bibliográfia a lábjegyzetekben. ISBN 9786155411564

- A Szegedi Tudományegyetem Állam- és Jogtudományi Karának oktatói, pályatársai, illetve a Civilisztikai Tudományok Intézete e kötettel köszöntötte Tóthné Fábián Esztert jogászi pályafutásának 60. évfordulójának alkalmából. Az ünnepelt a kar nagyra becsült oktatója, címzetes egyetemi tanár, aki a családjogra fókuszáló oktatási-kutatási tevékenysége mellett kiemelt figyelmet fordít a joggyakorlat problémáira. A kötet 46 tanulmányt tartalmaz. A szerzők többsége családjogi, személyiségi jogi, illetve a gyermekek jogaihoz kapcsolódó munkákkal köszönti az ünnepeltet, emellett olvashatunk a polgári perrendtartásról, a pszichologikáról, illetve a Brexitröl is. (T. F.)

\section{- Polgári Jog: Családjog}

Hegedüs Andrea

Harmadik, hatályosított kiadás. R.I.M.Á.K., Szeged, 2017

Tankönyv. Terjedelem: 378. Bibliográfia: 377-378. és a lábjegyzetekben.

ISBN 9789631299441

- A szerző a Szegedi Tudományegyetem oktatója, gyakorló jogász, a családjog szakértője. A mű első kiadása 2014-ben jelent meg, az új Ptk. alapján (ismertetése a Pro Futuro 2016/1. számában). Ezt követően azonban a törvényhozó számos, a családjog területét is érintő jogszabályt alkotott. A harmadik kiadásban ezeket a változásokat mutatja be. A könyv átfogóan elemzi a nemzetközi magánjogról és a polgári perrendtartásról szóló, 2018. január 1-jén hatályba lépett kódexeknek a Ptk. családjogi szabályaira gyakorolt hatásait. A tankönyv jól áttekinthetö, a normaszöveg elemzése mellett a vonatkozó bírói gyakorlatot is bemutatja. Segítségül szolgálhat nemcsak az egyetemi hallgatók, hanem a gyakorló jogászok számára is. (B. S.)

- 60. Studia in honorem Péter Miskolczi-Bodnár Homicskó Árpád Olivér-Szuchy Róbert (szerk.) (Sorozat: De iuris peritorum meritis, ISSN 1789-0896; 11.) 
KRE ÁJK, Budapest, 2017

Tanulmánykötet. Terjedelem: 619. Bibliográfia a lábjegyzetekben. ISBN 9789639808805

- A Károli Gáspár Református Egyetem Állam- és Jogtudományi Kara jelen kötettel ünnepli Miskolczi-Bodnár Péter professzor 60. születésnapját. Az ünnepelt az országban elsőként szervezte meg a Miskolci Egyetemen a kereskedelmi jog (magánjogtól elkülönült) oktatását, jelenleg a KRE tanszékvezető egyetemi tanára. A könyvben munkássága és szakmai teljesítménye elött nemcsak a közvetlen kollégák, hanem a barátok, pályatársak, családtagok, illetve egykori doktoranduszai fejezik ki tiszteletüket. Szakmai önéletrajzának bemutatását követően a kötetben 53 tanulmány szerepel magyar, angol és német nyelven. A szerzők a polgári és a kereskedelmi jog közelítésének témáján belül foglalkoznak többek között fogyasztóvédelmi joggal, versenyjoggal, a gazdasági társaságokkal, illetve a személyiségi jogvédelemmel. (T. F.)

- A magyar magáncsőd kézikönyve. A 2015. évi CV. törvény és végrehajtási rendeleteinek elöírásai a természetes személyek adósságrendezési eljárásáról JuHÁsz László

HVG-ORAC, Budapest, 2017

Kézikönyv. Terjedelem: 533. Bibliográfia a lábjegyzetekben.

ISBN 9789632583228

- A szerző nyugalmazott táblabíró, címzetes egyetemi docens, egy neves ügyvédi iroda munkatársa. A kötet a természetes személyek adósságrendezési eljárásáról szóló törvényt taglalja; az első olyan munkának tekinthető, amely a magáncsőd intézményét dolgozza fel. Viszonylag korai megjelenéséig bírói gyakorlat még nem alakulhatott ki, ezért a könyv a korábbi gyakorlatot ismerteti, és elsősorban az anyagi és eljárásjogi szabályok bemutatására törekszik. Először a magáncsőd alapelveit, majd a bíróságon kívüli és a bírósági adósságrendezési eljárást mutatja be, eközben a számos pozitívum mellett hangsúlyt fektetve a negatívumok értékelésére is. A függelékben megtalálható a témához kapcsolódó 17 végrehajtási rendelet szövege. Gördülékeny stílusa és jó szerkezete alapján a kézikönyv nemcsak a bírák, ügyvédek, valamint családi csődvédelem dolgozói számára lehet érdekes, hanem akár a jogkereső adósoknak is nagy segítséget nyújthat az eligazodásban. (G. B.)

- Brüsszeltöl Brüsszelig. Tanulmányok az európai polgári eljárásjog köréből KENGYel Miklós

(Sorozat: Acta Caroliensia Conventorum Scientiarum luridico-Politicarum, ISSN 2063-4757; 17.)

KRE ÁJK, Budapest, 2017

Monográfia. Terjedelem: 288. Bibliográfia a lábjegyzetekben. ISBN 9789634131618

- A szerző a Károli Gáspár Református Egyetem Állam- és Jogtudományi Karának egyetemi tanára volt (1953-2017). A mü közel negyed évszázad kutatómunkájának gyümölcse, amely kutatás kezdete a rendszerváltozásig, az európai polgári eljárásjog jogintézményének megformálásáig nyúlik vissza. A címben a „Brüsszel- 
töl Brüsszelig" az európai polgári eljárásjog fejlődésének történetére utal, ugyanis a legfontosabb jogforrások írásba foglalásának helyszínéül Európa fővárosa szolgált. A Brüsszeli Egyezményt felváltó Brüsszel I. rendelet alkalmazása komoly kihívást jelentett hazánkban, amelynek nehézségeit a szerző saját empirikus vizsgálatai alapján mutatja be. A kötet utolsó fejezetei a végrehajthatóvá nyilvánítási eljárás eltörlésével, valamint a rendelet megújitásával foglalkoznak. (T. N.)

- A társasházi törvény magyarázata. A társasházakról szóló 2003. évi CXXXIII. törvény és az irányadó bírói gyakorlat bemutatása

KIss Gábor

HVG-ORAC, Budapest, 2017

Kézikönyv. Terjedelem: 298. Bibliográfia: 297-298. ISBN 9789632583235

- A szerző a Kúria társasházi jogvitákat is elbíráló, dologi jogi tanácsának a tagja, aki már több alkalommal is foglalkozott a társasház intézményének bemutatásával. A kézikönyv a társasházakról szóló törvény magyarázatára és a hazai bírói gyakorlat részletes bemutatására törekszik. A teljesség igényével dolgozza fel a törvényt, a kapcsolódó háttérjogszabályokat, a szakirodalmat és a bírói gyakorlatot, különösen bírósági határozatok és a Kúria elvi határozatai alapján. A kötet szerkezete a törvény fejezeteit követi, a végén található függelékben pedig egy társasházi alapító okiratot mutat be. Mivel ezt az okiratot az életben kialakult helyzetek alakítják, a szerző hangsúlyozza, hogy a minta csupán alapot szolgáltat az ilyen okirat megírásához, és említ néhány példát, hogy milyen esetekben kell eltérni tőle. Elsősorban gyakorló jogászok, ügyvédek, bírák számára nyújt eligazítást, de hasznos lehet a közös képviseletet ellátó magánszemélyek és vállalkozások, valamint a tulajdonostársak számára is. (G. B.)

- A magánjog általános tana

LÁBADY Tamás

Szent István Társulat, Budapest, 2017

Tankönyv. Terjedelem: 258. Bibliográfia: 235-242. ISBN 9789632774589

- A 2016-os kiadás változatlan utánnyomása. A 2016-os kiadás annotációját lásd a Pro Futuro 2018/2. számában. (T. F.)

- Polgári jog: szerzői jog és iparjogvédelem

LonTAI Endre-Faludi Gábor-GyeRTYánFI Péter-VÉKÁs Gusztáv

(Sorozat: ELTE Jogi Kari Tankönyvek, ISSN 2060-6494; 15.)

ELTE Eötvös Kiadó, Budapest, 2017

Tankönyv. Terjedelem: 446. Bibliográfia a fejezetek végén. ISBN 9789633122709

- A szerzők egyetemi oktatók és szabadalmi joggal foglalkozó szakemberek. A könyv első kiadása 2012-ben jelent meg (ismertetése a Pro Futoro 2014/2. számában). A kötet újdonsága a közös jogkezelés új uniós és hazai szabályozásával foglalkozó fejezet teljes átírása, kiegészítve a joggyakorlási forma lényegének bemutatásával. A kötetben a korábbiaknál hangsúlyosabban jelenik meg a joggyakorlat, az Európai Bíróság és a magyar bírói gyakorlat bemutatása révén. A mủ végén függelék formájában a szerzők összefoglaló áttekintést nyújtanak az 
iparjogvédelem szervezetének felépítéséröl. A tankönyv jól áttekinthető felépítése, nyelvezete megkönnyíti az egyetemi hallgatók számára a szerzői joggal és iparjogvédelemmel kapcsolatos tananyag elsajátítását. (B. S.)

- A trust bevezetése Magyarországon és a nemzetközi gyakorlat. Válogatott tanulmányok a STEP Hungary 2014., 2015. és 2016. évi konferenciáján elhangzott elöadások alapján (Introduction of the trust in Hungary and the international practice: selected studies based on the lectures held on the conferences of STEP Hungary in the years 2014, 2015 and 2016)

Menyhei Ákos-Sándor István (szerk.)

HVG-ORAC, Budapest, 2017

Tanulmánykötet. Terjedelem: 229. Bibliográfia a lábjegyzetekben.

ISBN 9789632583259

- A kötet szerzői egyetemi oktatók, illetve gyakorló jogászok. A könyv az utóbbi években a Society of Trust and Estate Practitioners (STEP) nemzetközi szervezet által Budapesten megrendezett konferenciákon, magyar és angol nyelven megtartott, válogatott előadások szerkesztett változatait tartalmazza. A konferenciasorozat célkitűzése az volt, hogy a Ptk. hatálybalépésével a magyar jogrendszerben meghonosodó bizalmi vagyonkezelési konstrukciót átfogóan bemutassa. Olvashatunk a STEP müködéséröl, valamint az új jogintézményt érintő, magyar szabályozással kapcsolatos magán- és közjogi kérdésekröl. Ezen túlmenően, angol nyelven a jogintézményt használó néhány állam (Szingapúr, Hongkong, Oroszország, Liechtenstein) vonatkozó szabályozását és joggyakorlatát elemző írások is megtalálhatóak a müben. (B. S.)

- A bizalmi vagyonkezelés. Jogalkalmazási és jogalkotási alapkérdések jelenlegi és jövőbeli vagyonrendelöknek, vagyonkezelöknek, kedvezményezetteknek és a kezelt vagyon hitelezőinek

MiczÁn Péter

HVG-ORAC, Budapest, 2017

Monográfia. Terjedelem: 525. Bibliográfia: 507-525. ISBN 9789632583389

- A szerző a Nemzetgazdasági Minisztérium szakmai tanácsadója, 2017 őszén az Eötvös Loránd Tudományegyetemen védte meg „A bizalmi vagyonkezelés - Szabályozási alapkérdések és javaslatok" címü PhD-doktori értekezését. A könyv a disszertáció átdolgozásával jött létre. A mű célja a Ptk. hatálybalépésével a magyar jog rendszerébe az angolszász jogrendszerből beemelt bizalmi vagyonkezelési konstrukció alapvető dologi és kötelmi jogi sajátosságainak a bemutatása, így elösegítve a joggyakorlat hatékonyságát. A mủ a tudományos analízis eszközrendszerének, módszereinek rövid felvázolásával kezdődik, majd a jogviszony tartalmi elemeinek elemzésével folytatódik. A jogviszony-analízis keretén belül többek között bemutatja a hárompólusú jogviszony alanyainak jogállását, felelősségét, sorra veszi a szerződés létrehozásának, módosulásának, megszünésének alapkérdéseit. A mü végén átfogó, minden részletre kiterjedő szerződésminta található, amely a gyakorló jogászok munkáját segíti. (B. S.) 
- Polgári eljárásjogi ismeretek igazságügyi igazgatás szakos hallgatók számára Molnár Judit-nYILAs Anna-Pribula László-ZákÁnY Judit

Debreceni Egyetemi Kiadó, Debrecen, 2017

Egyetemi jegyzet. Terjedelem: 212. Bibliográfia: 210-212. ISBN 9789633186275

- A szerzők a Debreceni Egyetem oktatói. Három nagy szerkezeti egységre osztható a könyv: az első a perjog általános szabályait mutatja be (hatáskör, felek, elsőfokú eljárás, bizonyítás, határozatok), a második rész az egyes perorvoslatokkal és a különleges perek szabályaival foglalkozik, míg a harmadik egység a nemperes eljárásokat, valamint az európai polgári eljárásokat taglalja (például a határozatok kölcsönös elismerését és végrehajtását, illetve az európai fizetési meghagyásos eljárást). Alapvetően nem ismétli meg a jogszabályok pontos szövegét, csupán a jogszabályhelyekre hivatkozva rendszerezi az eljárásjogi szabályokat abból a célból, hogy segítséget nyújtson a hallgatók számára a tanuláshoz. A szerkesztés révén és a szabályok lényegének kiemelésével kiválóan hasznosítható az igazságügyi igazgatási alapszakos hallgatók számára, akik a tankönyv segítségével megszerezhetik a szükséges tudást, és eredményesen felkészülhetnek a polgári eljárásjogi vizsgára. (K. A.)

- Polgári eljárásjog I. Nagy Adrienn-Wopera Zsuzsa (szerk.)

Wolters Kluwer, Budapest, 2017

Tankönyv. Terjedelem: 367. Bibliográfia a lábjegyzetekben. ISBN 9789632957005

- A kötet szerzői egyetemi oktatók, gyakorló jogászok. A tankönyv struktúrája elsősorban a polgári perrendtartás szerkezetén alapul, azonban nem követi azt olyan mértékben, mint ahogyan egy kommentár, és alapvetően nem ismerteti a normaszöveget sem. Az első kötet tartalmát az alapelvek, és polgári perjog általános szabályai (például: hatáskör, illetékesség, felek, költségek), az elsőfokú eljárás, a bizonyítás és a határozatok képzik. A könyv erénye, hogy a bírói gyakorlat bemutatásának is hangsúlyos szerepet szántak a szerzők. A tételes jogi rendelkezések részletezését megelőzően az olvasó megismerkedhet a polgári eljárásjog alapvető fogalmaival, emellett a magyar perjog elmúlt másfél évszázadának fejlődéstörténetébe is betekintést nyerhet. A mü remekül hasznositható oktatási tevékenységhez, illetve az egyetemi hallgatók vizsgára történő felkészülésére is kiválóan alkalmas, a II. kötettel kiegészülve. (K. A.)

- Nemzetközi magánjog

NAGY Csongor István

Harmadik, átdolgozott és bővített kiadás. HVG-ORAC, Budapest, 2017 Tankönyv. Terjedelem: 352. Bibliográfia: 344-350. ISBN 9789632583549

- A szerző az SZTE ÁJTK Nemzetközi Magánjogi Tanszékének tanszékvezető egyetemi tanára. Munkája a 2011-es és 2012-es köteteket követő harmadik, átdolgozott, bővített kiadás. A könyv alapjául egyrészt a nemzetközi magánjogról szóló új jogszabály, a 2017. évi XXVIII. törvény, másrészt az irányadó európai uniós rendeletek és európai bírósági ítéletek szolgáltak. A nemzetközi magánjog fogalmának és forrásainak bemutatását követően három nagyobb szerkezeti egység 
különíthetö el. Ezek részletesen ismertetik a kollíziós jog általános, illetve különös részét, továbbá a nemzetközi polgári eljárásjogot. A korábbi két kiadás annotációja a Pro Futuro 2013/1. és 2014/2. számában olvasható. (F. B.)

- A jogerő tárgyi terjedelme a polgári perben. Az érvényesitett jog és a jogerő öszszefüggései

PÁKOZDI Zita

lurisperitus, Szeged, 2017

Monográfia. Terjedelem: 144. Bibliográfia: 133-141. ISBN 9786155411526

- A mú szerzője a Szegedi Tudományegyetem oktatója, e monográfia az ugyanezen címmel rendelkező doktori értekezésének továbbdolgozott változata. Hiánypótló jellegű alkotásnak minősül, hiszen Farkas József négy évtizeddel ezelőtti munkája óta ilyen kutatás nem érintette a jogerő polgári eljárásjogi kérdéskörét. A szerző alapvetően elméleti síkon közelíti meg a témát, és a domináns elemző szemlélet mellett a jogszabály-értelmezési és a jog-összehasonlító módszer alkalmazását sem nélkülözi. A dogmatikai megközelítés mellett kitér a bírósági gyakorlatra is. A monográfia kilenc nagy szerkezeti egységből épül fel, amelyek közül négy a jogerő más államok (Németország, Ausztria, Franciaország, Anglia) perjogi megközelítését taglalja. A problémafelvetés után az alapvető kontextust tisztázza a szerző, majd a jogerő magyar perjogban betöltött szerepére koncentrál. Az összegzésben a hipotézisként megfogalmazott tételeket igazolja a szerző. (K. A.)

- A végrehajtó és az adós, a bírósági végrehajtás gyakorlati ütközőpontjai [A végrehajtó és az adós, a birósági végrehajtás a gyakorlatban]

PATAKI János István

Budapest, Expert Books, 2016

Monográfia. Terjedelem: 222. Bibliográfia: 215-217. és a lábjegyzetekben. ISBN 9786155014765

- A 2013-as kiadás változatlan utánnyomása. Az első kiadás annotációját lásd a Pro Futuro 2015/1. számában. (T. N.)

\section{- Polgári eljárásjog I-II. Kommentár a gyakorlat számára}

Petrik Ferenc (szerk.)

Harmadik kiadás. HVG-ORAC, Budapest, 2017

Kommentár. Terjedelem: 1339. Bibliográfia: nincs. ISBN 9638213086

- A jogalkalmazás gyakorlott szakértői, köztük a Kúria bírái, az új polgári perrendtartásról szóló törvény elfogadása után egy nagykommentár készítését vállalták, amelyet időről időre aktualizálnak. A munka célja, hogy egyrészt elemezze, hogy a kialakult bírói gyakorlat mennyiben alkalmazható az új polgári perrendtartás hatálya alatt indult eljárásokban, másrészt útmutatást adjon arról, hogy az új perrendtartás bonyolult rendszerében a rendelkezések miként függenek össze egymással, és hogyan viszonyulnak a kapcsolódó egyéb jogszabályok rendelkezéseihez. A szerzők nem a jogszabály szakaszról szakaszra történő ismertetését célozzák, hanem az eljárásjogot a maga dinamikájában, a bírói gyakorlatban megjelenő „élő” változatában kívánják bemutatni. (Sze. B.) 
- Különbözőség az egységben. A szerzői jogi szabályozás differenciálódásának hatása a jogterület szerepére és hatékonyságára

PogÁcsás Anett

(Sorozat: Doktori Értekezések, ISSN 2064-1907; 15)

Pázmány Press, Budapest, 2017

Monográfia. Terjedelem: 340. Bibliográfia: 277-340. és a lábjegyzetekben. ISBN 9789633083185

- A szerző a PPKE JÁK adjunktusa, e munkájának alapja a doktori (PhD) disszertációja. A jelenlegi jogirodalomban egymástól eltérő vélemények alakultak ki a szerzői jogról. E jogterület jövőbeli feladatának tisztázásához szükséges vizsgálni, hogy az eredeti szerepe mennyiben változott napjainkban. Így az értekezés azon kérdésköröket mutatja be, hogy vajon ellentétes irányba haladnak-e a szerzői jog jövőjét vázoló különböző elképzelések, vagy elérhető valódi kompromisszum is, illetve ezzel összefüggésben a szerzői jog hatékonyságának növeléséhez, a jogterület modernizálásához szükség van-e paradigmaváltásra. Mindezeken túl a mű taglalja a szerző személyéhez való viszonyulás differenciáltságának, az eredeti jogosult és múve, valamint az eredeti jogosult és a közvetítők, a közönség viszonyának jelentőségét. A mű szerkezeti egységei a bevezetés, három fejezet, a zárszó és a bibliográfia. Az egyes következtetéseket a fejezetek végén foglalja össze a szerző. (B. E.)

- Nemzetközi magánjog. Jogszabály- és jogesetgyüjtemény Szabó Sarolta (föszerk.) (Sorozat: Pázmány Péter Katolikus Egyetem Jog- és Államtudományi Karának tankönyvei, ISSN 2062-0837)

Második, javított és bővített kiadás. Pázmány Press, Budapest, 2017

Tansegédlet. Terjedelem: 490. Bibliográfia a lábjegyzetekben.

ISBN 9789633082935

- A kötet a PPKE JÁK Nemzetközi Magánjogi Tanszékének oktatói közreműködésével készült. Célja, hogy a napjainkra nagymértékben megnövekedett terjedelmủ nemzetközi magánjogi joganyagot áttekinthetővé tegye mind a joghallgatók, mind a gyakorló jogászok számára, így a tételes joganyagot és a jogesetgyűjteményt feladatokkal, kérdésekkel egészíti ki. A kötet a 2013-ban megjelent első kiadás javított, bővített változata, így a gyüjtemény a 2013 óta meghozott magyar ítélőtáblai, kúriai döntések, valamint az Európai Unió Bíróságának ítélkezési gyakorlata tekintetében egyaránt gyarapodott. Az első kiadás annotációja a Pro Futuro 2015/1. számában olvasható. (F. B.)

- Agrárjog. A magyar agrár- és vidékfejlesztési jogi szabályozás lehetőségei a globalizálódó Európai Unióban

Szilágyi János Ede (szerk.)

Miskolci Egyetemi Kiadó, Miskolc, 2017

Tankönyv. Terjedelem: 303. Bibliográfia az egyes fejezetek végén és a lábjegyzetekben. ISBN 9786155626166 
- A szerzők túlnyomóan a Miskolci Egyetemhez kötődő oktatók, kutatók, de többen közülük figyelemre méltó gyakorlati tapasztalatokkal is rendelkeznek. A kötet tematikai változatossága, $\mathrm{s}$ ugyanakkor az agrárjog részterületei tekintetében a teljeskörüségre törekvés hiánya kiválóan szemlélteti, hogy a hatalmasra duzzadt joganyag és szakirodalom az oktatásban megengedi, és igényli is a válogatást (adott esetben más tantárgy tematikájához rendelést), részben didaktikai szempontok alapján. Az agrárjog elméleti alapjain és az egyes alágazatok szakigazgatási területein túl, például a földforgalmi szabályozás, a mezőgazdasági vízgazdálkodás, az agrárnyilvántartások és a szellemi tulajdonvédelem egyes területei is helyet kaptak itt. A kötet egyes fejezetei kifejezetten tudományos igényességgel íródtak, míg mások közelebb állnak az oktatás valós igényeihez. A nehezen követhető, gyakran változó szabályozásra tekintettel fontos, hogy időröl időre készüljenek hasonló leírások és elemzések. (F. L.)

- Szellemi alkotások joga

TatTAY Levente-PInTZ György-Pogácsás Anett

Szent István Társulat, Budapest, 2017

Tankönyv. Terjedelem: 395. Bibliográfia: 385-395. ISBN 9789632777115

- A mű a 2011-es kiadás változatlan utánnyomása. A 2011-es kiadás ismertetését lásd a Pro Futuro 2013/1. számában. (B. S.)

- A polgári perrendtartás: 1952-2016

То́тн Barbara

Wolters Kluwer, Budapest, 2017

Jogszabálytükör. Terjedelem: 602. Bibliográfia nincs. ISBN 9789632956961

- A szerző egyetemi tanársegéd a Miskolci Egyetem Állam- és Jogtudományi Kar Polgári Eljárásjogi és Nemzetközi Jogi Tankszékén. A polgári perrendtartásról szóló 1952. évi III. törvény és a polgári perrendtartásról szóló 2016. évi CXXX. törvény közötti jogszabályi változások egybevetését, összefoglalását tűzte ki célul. Az új perrendtartásban jelentősen módosultak a jogi képviseletre vonatkozó szabályok, bevezette az osztott perszerkezetet az elsőfokú eljárásokban, a perfelvételi iratok kiemelt szerepet kaptak éppúgy, mint a felek jognyilatkozatai. Új alapokra helyezte a szakértői bizonyítást, és jelentősen változtak a másodfokú eljárás szabályai is. A változásgyűjtemény ezért hasznos segítséget nyújt az új törvény megértéséhez és annak alkalmazásához elsősorban azok számára, akik a régi törvényt és annak gyakorlatát már ismerik. A régi Pp. és az új 2016-os Pp. rendelkezéseit párhuzamosan jeleníti meg, a dokumentum bal oldalán a régi jogszabályi rendelkezések, míg a jobb oldalán az új, jelenleg hatályos jogszabályi rendelkezések helyezkednek el. (Sze. B.)

\section{- Felelősségtan}

UJVÁRINÉ AnTAL Edit

(Sorozat: Magister Kötetek, ISSN 2498-5430)

Patrocinium, Budapest, 2017

Tankönyv. Terjedelem: 222. Bibliográfia: 212-220. ISBN 9789634131519 
- A szerző a Miskolci Egyetem jogi karának oktatója, a polgári jogi felelősségtan szakértője. E munkája a joghallgatók, illetve a szakvizsgára készülők számára nyújt ismereteket a kártérítési jog területén. A mű előzményéül szolgált a Novotni Alapítvány által az 1990-es évek közepétöl kiadott Felelősségtan jegyzet, amelynek újragondolása a 2013. évi V. törvény (Ptk.) hatálybalépésére tekintettel vált szükségessé. A hét részre tagolt könyv a jogi felelösség és a polgári jogi felelösség alapkérdéseinek tisztázását követően foglalkozik a szerződésen kívül okozott károkozással, a kártérítési kötelezettség terjedelmével, a felelősség egyes eseteivel, a szerződésszegéssel okozott kárfelelősség szabályaival, a kártérítés más jogterületektől való elhatárolásával, illetve a polgári jogi kártérítési szabályok más jogterületeken történő alkalmazásával. A szerző e témák kifejtése során különös hangsúlyt fektet a bírói gyakorlat ismertetésére is. (T. F.)

- Az új Pp. iratmintatára. Beadványtervezetek az új Pp. minden eljárási cselekményéhez, összesen 388 iratminta

Varga István-Gelencsér Dániel (szerk.)

HVG-ORAC, Budapest, 2017

Iratmintatár. Terjedelem: 1062. Bibliográfia nincs. ISBN 9789632583556

- Az iratmintatár szerzői több hivatásrend képviselői: van köztük bíró, ügyvéd, közjegyző és egyetemi oktató is. A szerkesztő ügyvéd, illetve az Eötvös Loránd Tudományegyetem oktatója. A vaskos kötetben a felek, illetve a képviselők által benyújtandó beadványokra, kérelmekre irányadó mintákkal találkozhat az olvasó, olyanokkal, amelyek a hatályos Pp. által megkövetelt szigorúbb formai és tartalmi követelményeknek megfelelnek. Az egyes iratmintákat gyorstáblázat követi, amelyek a beadvánnyal kapcsolatos legfontosabb információkat tartalmazzák, mint például azt, hogy az eljárás mely szakaszában, milyen határidővel, milyen melléklettel és mely perbeli szereplő által terjeszthető elő a beadvány. $(K . A$.)

- A polgári perrendtartásról szóló 2016. évi CXXX. törvény magyarázata Wopera Zsuzsa (szerk.)

Wolters Kluwer, Budapest, 2017

Kommentár. Terjedelem: 722. Bibliográfia a lábjegyzetekben.

ISBN 9789632956947

- A szerzők egyetemi oktatók és gyakorló jogászok (bírák, ügyvéd és önálló bírósági végrehajtó), akik valamennyien részt vettek az új polgári perrendtartás kodifikációjában. A kötet szerkesztője a Miskolci Egyetem polgári eljárásjogász professzora, a kodifikációért felelős miniszteri biztos. A mű alapvetően a polgári perrendtartásról szóló törvény szerkezetét követi olyan módon, hogy a jogszabály szövegét követi a normaszöveghez füzött részletes és kimerítő magyarázat, amelyből megismerhetjük az adott rendelkezés célját és lényegét. A számtalan jogirodalmi hivatkozáson túl a kötet érdemei közé tartozik, hogy mindig ismerteti a releváns jogtörténeti megoldásokat, illetve nemzetközi kitekintés keretében az olvasó megismerheti egyes perjogi rendszerek, elsősorban a német, osztrák és svájci perrendtartás megoldásait is. A magyarázat segítségül szolgálhat mind a polgári eljárásjog oktatásához, mind a jogalkalmazásban a jogszabály szövegének értelmezéséhez. (K. A.) 


\section{VEGYES TÁRGYÚ TANULMÁNYKÖTET}

- Jogtudomány a jogfejlődés szolgálatában. Szemelvények a modern jogi kutatások köréböl

Szikora Veronika-Árva Zsuzsanna (szerk.)

DE ÁJK, Debrecen, 2017

Tanulmánykötet. Terjedelem: 235. Bibliográfia a lábjegyzetekben. ISBN 9789631293166

- A szerzők a debreceni jogi kar oktatói, doktoranduszai és joghallgatói. A kötet az Igazságügyi Minisztérium által támogatott kutatási program eredménye, amelynek sajátossága, hogy egy-egy oktató egy-egy graduális vagy doktorandusz hallgatóval közösen vett részt benne, így tizenkét oktatói-hallgatói kutatócsoport jött létre a legkülönbözőbb jogi témákra fókuszálva. A programot lezáró tanulmányok többek között az Európai Unió Bíróságával, a fogyasztói jogviták alternatív rendezésével, az államfők nemzetközi jogi felelősségével, a parlamenti képviselök mentelmi jogával és a vagyon elleni büncselekményekkel foglalkoznak. (F. F.) 